\title{
Impact of horizontal resolution on monsoon precipitation for CORDEX-South Asia: A regional earth system model assessment
}

\author{
Alok Kumar Mishra ${ }^{\text {a, Pankaj Kumar }}{ }^{\text {a, },}$, Aditya Kumar Dubey ${ }^{\mathrm{a}}$, Aaquib Javed ${ }^{\mathrm{a}}$, \\ Md Saquib Saharwardi ${ }^{a}$, Dmitry V. Sein ${ }^{\mathrm{b}, \mathrm{c}}$, Stanislav D. Martyanov ${ }^{\mathrm{c}}$, Daniela Jacob ${ }^{\mathrm{d}}$ \\ a Department of Earth and Environmental Sciences, Indian Institute of Science Education and Research Bhopal, India \\ ${ }^{\mathrm{b}}$ Alfred Wegener Institute for Polar and Marine Research, Bremerhaven, Germany \\ ${ }^{\mathrm{c}}$ Shirshov Institute of Oceanology, Russian Academy of Sciences, Moscow, Russia \\ ${ }^{\mathrm{d}}$ Climate Service Center, Germany
}

\section{A R T I C L E I N F O}

\section{Keywords:}

Regional earth system modelling

Indian monsoon

Horizontal-resolution

Air-sea interaction

CORDEX-SA

\begin{abstract}
A B S T R A C T
For the first time for CORDEX-South Asia, a high-resolution regional earth system model (ROM) is adopted to assess the impact of horizontal resolution $\left(0.22^{\circ}\right.$ and $\left.0.11^{\circ}\right)$ in simulating the Indian summer monsoon rainfall (ISMR) and the underlying spatiotemporal variability. ROM at both resolutions bears a close resemblance to observations in simulating the mean precipitation climatology compared to other regional climate models (RCMs) participated in CORDEX-South Asia. ROM shows substantial improvement relative to the ensemble mean of the RCMs included in CORDEX-South Asia. While comparing both simulations with observations, some systematic wet and dry bias over Central India (CI) and Northern Western Ghats is noticed. In general, the wet/dry bias over India is mainly associated with the overestimation/underestimation of the large-scale/convective component. Increasing horizontal resolution from $0.22^{\circ}$ to $0.11^{\circ}$ significantly adds value in simulating the JJAS mean precipitation by reducing the wet bias over western central India (WCI) and southern peninsular India and dry bias over eastern CI. The reduction in wet/dry bias is mainly associated with suppression/enhancement of the large scale/convective precipitation. This improvement in mean precipitation is partially due to the improved representation of the propagation of mesoscale systems such as boreal summer intraseasonal oscillation (eastward and northward). Despite the above improvements, the wet precipitation bias, particularly over WCI, persists. The weaker Findlater Jet associated with weaker land-ocean thermal contrast caused by the warm sea surface temperature (SST) bias over the western Arabian Sea (AS) suggests that AS moisture transport does not contribute to the wet bias over India. The wet bias is possibly associated with favourable atmospheric conditions (atmospheric instability).
\end{abstract}

\section{Introduction}

The importance of the skilful prediction of the Indian summer monsoon rainfall (ISMR) at various timescales has posed a considerable challenge for scientific and regional planning managers over the decades. ISMR affects not only the agricultural sector, hydropower, and mining but also the various allied sectors, and hence the gross domestic product (GDP) of the Indian economy (Goswami, 2005) and the lives of its people. The Indian summer monsoon (ISM) is a coupled atmosphereocean phenomenon (Charney and Shukla, 1981; Sahai et al., 2003), and the correct representation of the ocean-atmosphere interaction in models is vital for its accurate simulation (Fu et al., 2002; Zheng et al.,
2004; Jiang et al., 2004; Rajendran and Kitoh, 2006; Misra and Dirmeyer, 2009).

Various modelling studies show that air-sea coupling improves the climate variability in coupled atmosphere-ocean general circulation models (AOGCMs) concerning standalone atmospheric general circulation models (AGCMs) (Fu et al., 2002, 2007; Kumar et al., 2014a; Di Sante et al., 2019; Zhu et al., 2020; Cabos et al., 2020). Attempts have been made in the past to demonstrate the capability of AOGCMs to simulate the Indian summer monsoon (Chaudhari et al., 2013) by analyzing the available output of the Coupled Model Intercomparison Project (CMIP5; Taylor et al., 2012; Eyring et al., 2016). Most of the studies reported a significant bias in simulating ISMR over India,

\footnotetext{
* Corresponding author at: Department of Earth and Environmental Sciences, Indian Institute of Science Education and Research Bhopal, India.

E-mail address: kumarp@iiserb.ac.in (P. Kumar).
} 
possibly due to their coarse resolution (Chaudhari et al., 2013). Horizontal resolutions of CMIP5 atmospheric models are typically $\sim 200 \mathrm{~km}$ $(\sim 150 \mathrm{~km})$ or coarser in the atmosphere. Such a coarse resolution model is not capable of resolve the orography in complex regions such as the steep topography of the Himalayas and the Western Ghats and various important climate processes such as atmospheric convection and mesoscale boundary currents and eddies and subgrid-scale processes (Tiedtke, 1996; Jakob and Klein, 1999; Stephens et al., 2004; Kumar et al., 2006: Kumar et al., 2013; Barker et al., 2016; Mishra and Dwivedi, 2019) and has to be parameterized, which may compromise dynamic processes and their interactions (Collins et al., 2018). Increased resolution correctly represents the orography of the region and the local features, such as the propagation of mesoscale systems (Vellinga et al., 2016; Mandke et al., 2020).

In recent decades, high-resolution regional climate models (RCMs) are widely employed to dynamically downscale the available output of the global general circulation models (GCMs) or reanalysis (Rupa et al., 2006; Mukhopadhyay et al., 2010; Ratnam et al., 2017; Bhatla et al., 2020; Mishra et al., 2020a, 2020b). Most of the studies reported an improvement in simulating the ISM characteristics due to the better representation of the regional forcings, such as the mountain orography, physical processes, and interactions (Chan et al., 2013; Jacob et al., 2014; Mishra et al., 2020b) however, the dry bias over India still persists, partly due to absence of fine-scale regional air-sea interactions (Lucas-Picher et al., 2011). The performance of the RCMs is subjected to various constraints such as convective parameterization scheme (CPSs), land surface interaction, domain size, and resolutions, and the accuracy of initial and boundary conditions (ICBC) (Mukhopadhyay et al., 2010; Jacob et al., 2012; Giorgi et al., 2012; Dash et al., 2014; Mishra and Dwivedi, 2019; Sinha et al., 2019). Various studies reported that increasing the horizontal resolution leads to explicitly resolving the process (Hack et al., 2006; Kendon et al., 2012) and consequently reducing the uncertainty in simulating precipitation over India. However, some studies observed the negligible influence of increasing resolution toward improving the simulated fields (Chan et al., 2013; Li et al., 2014). Even diminishing performance was noted in the study of Mass et al. (2002).

The high-resolution coupled earth system model with realistic physics is most suitable to improve the predictability of ISMR. Rajendran and Kitoh (2008) reported significant improvement in the simulation of the spatial distribution of the precipitation over India using a highresolution global GCM at the $20-\mathrm{km}$ horizontal resolution. However, such high-resolution global models are computationally costly and demand substantial computational resources and storage requirements. An alternative approach is to employ the high-resolution regional earth system model (RESM). Various regional coupled models and earth system models of different complexity have been developed to study the regional climate variability and change over the different parts of the globe (Misra and Dirmeyer, 2009; Kumar et al., 2013; Turuncoglu et al., 2013; Turuncoglu and Sannino, 2017; Sein et al., 2015; Byrne et al., 2016; Cha et al., 2016; Cabos et al., 2019). In comparison to other parts of the globe, very few studies have used regional coupled atmosphereocean/RESM models to simulate the ISM characteristics (Ratnam et al., 2009; Samala et al., 2013; Misra et al., 2017; Di Sante et al., 2019). Moreover, the comparative assessment of the added value of these highresolution regional coupled models/RESM or the impact of horizontal resolution in the context of the ISMR is not yet explored. Peatman and Klingaman (2018) analyzed the impact of horizontal resolution in the coupled model and reported that increasing horizontal resolution from $200 \mathrm{~km}$ to $90 \mathrm{~km}$ improves the model's performance in simulating ISM characteristics. On the other hand, further increasing resolution from 90 $\mathrm{km}$ to $40 \mathrm{~km}$ produces slight improvement. High-resolution simulations are computationally expensive; therefore, it is better to access the added value (AV) of increasing horizontal resolution before doing production simulations. Suppose higher resolution produces insignificant or negligible improvements in reducing the misfit of the model. In that case, efforts should be made to deploy the computational resources elsewhere, such as increased ensemble size or improved additional model physics.

In this context, there is a great demand to access the potential of a high-resolution regional earth system model (RESM) to simulate the ISMR over India and associated dynamical and thermodynamical processes. One of the objectives of this study is to assess the skill of the highresolution RESM, namely ROM (Sein et al., 2015), to simulate the ISMR. Comparatively, fewer attempts have been made to assess the regional climate model's skill, REMO, over SA (Saeed et al., 2009, 2012; LucasPicher et al., 2011; Kumar et al., 2014a, 2014b, 2014c, 2015). Moreover, the REMO coupled with Max-Planck-Institute Ocean Model (MPIOM) has also been employed to simulate the atmosphere-ocean properties of different regions of the world (Aldrian et al., 2005; Paxian et al., 2016; Sein et al., 2015, 2020; Zu et al., 2019; Zhu et al., 2020) including SA (Kumar et al., 2013, 2014b, 2014c). However, earlier studies over SA using coupled regional model/RESM are restricted to horizontal resolution $\sim 50 \mathrm{~km}$ and short periods of less than a decade, which are not typically relevant time scales for climate studies, hence lacking confidence in the performance of the model for climate change projection over India.

In this study, we attempted to rigorously assess ROM's comparative performance at different horizontal resolutions in simulating the ISM characteristics over the CORDEX-South Asia domain over the past 38 years. This is the first comparative assessment study of the characteristics of ISM using ROM over India for such a long integration period (38 years) at a resolution of $0.22^{\circ}(\sim 25 \mathrm{~km}) / 0.11^{\circ}(\sim 12 \mathrm{~km})$. This study investigates the impact of increasing horizontal resolution in simulating the ISM characteristics over SA and the associated dynamical and thermodynamical processes. The regional spatiotemporal variability of precipitation reveals significant heterogeneity. Therefore we also assess the skill of the model in terms of different statistics such as the areaaveraged mean, root mean square error (RMSE), standard deviation (std), and correlation coefficient (cc), over India as a whole as well as over six Indian homogeneous monsoon rainfall regions (IHMRR) (Parthasarathy et al., 1996), such as Northwest India (NWI), Northeast India (NEI), West Central India (WCI), Central Northeast India (CNI), Peninsular India (PI), and Hilly Region (HR).

The previous studies based on RCMs or RESMs have attempted to investigate the bias in total seasonal precipitation. However, it is commendable to gain further insights into how the bias is contributed to by the partitioning of the convective scale (CS) precipitation and largescale (LS) precipitation to identify the strength/weakness of the physics in the model. Therefore, another objective of this study is to investigate the contribution of CS and LS precipitation bias of the total seasonal rainfall to help in identifying the weaknesses (if any) in the formulation precipitation of individual types of precipitation. The identification of sources of biases is in great demand to gain sufficient insight for further improving the physics of the existing model toward reducing the uncertainties, which is the last objective of this study. We organize the manuscript as follows. Section 2 briefly discusses the experimental design of the RESM along with its components. The results are presented in Section 3. Conclusions are drawn in Section 4.

\section{Model components and experimental design}

The RESM used in the study comprises a set of three models (i) REgional atmosphere MOdel REMO (Jacob, 2001) is atmospheric component, (ii) Max-Planck Institute Ocean Model (MPIOM) (Marsland et al., 2002; Jungclaus et al., 2013) is ocean component, and (iii) Hydrological Discharge model (HD) (Hagemann and Dümenil, 1997) is terrestrial hydrology component. REMO is a regional atmospheric model, while MPIOM and HD are global models. They are coupled using an OASIS coupler (Valcke et al., 2003). This coupled system is hereafter referred to as ROM. A detailed description of this coupled system is provided in Sein et al., 2015. The MPIOM and HD models are simulated 
globally and are coupled with REMO over the CORDEX-South Asia region (Fig. 1). In MPIOM, relatively high resolution over the Indian Ocean (IO) $\sim 20 \mathrm{~km}$ has been used. The HD model is simulated globally at a resolution of $0.5^{\circ}$. Over the coupled domain, the ocean and atmosphere exchange fields every three hours while the HD model receives surface runoff and drainage from REMO and delivers river runoff to MPIOM once per day. Lateral atmospheric and upper oceanic boundary conditions outside the REMO domain were prescribed using ECMWF ERA-Interim (EIN) reanalysis (Dee et al., 2011). After ca. 100 years of model spinup with the same MPIOM but $0.44^{\circ}$ REMO resolution, two sensitivity experiments of horizontal resolution are performed with ROM. REMO is integrated at $0.11^{\circ}$ and $0.22^{\circ}$, while MPIOM and the HD model grids are the same in both simulations.

\section{Results}

Both ROM simulations are compared to demonstrate the usefulness of increasing the horizontal resolution in simulating the mean characteristics of the ISM and associated dynamical and thermodynamical processes over South Asia.

\subsection{Mean monsoonal characteristics and the added value}

The comparative rationality of the model's performance at two different horizontal resolutions regarding the intensity and distribution of JJAS mean precipitation is assessed. Fig. 2a presents the JJAS mean precipitation for the IMD observation (Unnikrishnan et al., 2013), $\mathrm{ROM}_{0.22}$ (Fig. 2b), and $\mathrm{ROM}_{0.11}$ (Fig. 2c) for the study period 1980-2017. The figure depicts that the spatial distribution of simulated precipitation over India is reasonably close to the observations. The ROM clearly distinguishes the regions of low and high-intensity precipitation at both resolutions. For example, the Western Ghats, Northeast India (NEI), and Central India show a high precipitation value. These features are captured reasonably well by the ROM at both resolutions. The ROM (at both resolutions) overestimates the rainfall over the central Indian and southern peninsular region. Overall, the simulated precipitation distribution agrees with the observations for $\mathrm{ROM}_{0.22}$ and $\mathrm{ROM}_{0.11}$ with varying degrees of accuracy. The root mean square error (RMSE) of $2.7(2.5) \mathrm{mm} /$ day between the $\mathrm{ROM}_{0.22}\left(\mathrm{ROM}_{0.11}\right)$ and IMD rainfall is much smaller than the standard deviation $(4.5 \mathrm{~mm} /$ day) of IMD JJAS rainfall. This demonstrates the quality of the ROM simulated precipitation. Comparatively lesser RMSE in $\mathrm{ROM}_{0.11}$ compared to $\mathrm{ROM}_{0.22}$ confirms the advantage of increasing resolution.

It is interesting to note that despite performing reasonably well, ROM's JJAS precipitation bias pattern demonstrates strong heterogeneity, for example, the wet bias over CI, southern peninsular India (SPI), some part of NEI and Indo Gangetic Plains (IGP), and dry bias over the northern part of WG and central part of the NEI. This mean precipitation bias pattern, both wet and dry, of $\mathrm{ROM}_{0.11}$, is more or less in resemblance with the $\mathrm{ROM}_{0.22}$ Fig. 2; however, the magnitude of wet bias over CI, SPI, parts of NEI, and IGP, as well as the dry bias over northern WG is noticeably reduced in $\mathrm{ROM}_{0.11}$. This shows a clear advantage of increasing horizontal resolution over SA. However, the $\mathrm{ROM}_{0.11}$ shows an increase of dry bias over the central part of the NEI, probably due to the limitation of using the hydrostatic version at a higher resolution over the region with a complex interaction between the convective system and large-scale dynamics (Maurya et al., 2018). The magnitude of bias reported in this study is considerably less than that of the bias reported in earlier studies using RCM (Lucas-Picher et al., 2011; Kumar et al., 2014a, 2014b, 2014c, Bhatla et al., 2020; Kumar and Dimri, 2020) and coupled regional atmosphere-ocean model/RESM (Misra et al., 2017, 2018; Di Sante et al., 2019; Mishra et al., 2021).

Furthermore, the performance of our model is compared with dynamic downscaling simulations using the regional climate model (RegCM version 4; Giorgi et al., 2012), the Rossby Centre regional climate model version 4 (RCA4; Kupiainen et al., 2011), and the Canadian Centre for Climate Modelling (CCMA; Flato et al., 2000) for CORDEX-South Asia in which the same forcing of EIN has been used. These dynamically downscaled data sets were obtained from the Climate Data Portal hosted at the Centre for Climate Change Research (CCCR), Indian Institute of Tropical Meteorology (IITM), http://cccr.tropmet.res. in/home/cordexsa_datasets. The details of these RCMs are given in Table 1. Fig. 3 illustrates the comparison of JJAS mean bias of ROM and CORDEX-South Asia RCMs. The figure suggests a substantially greater
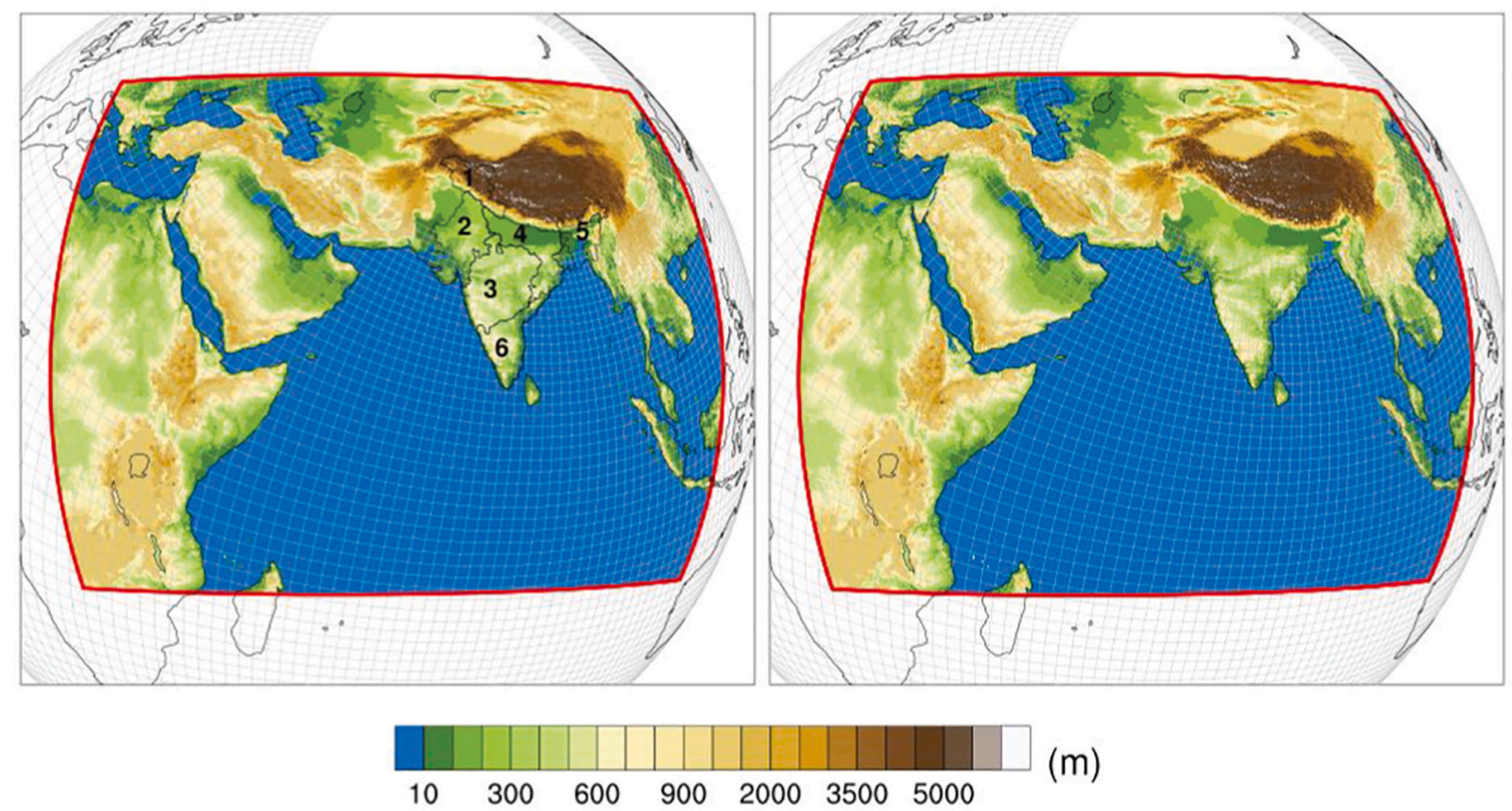

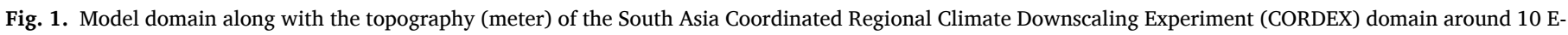

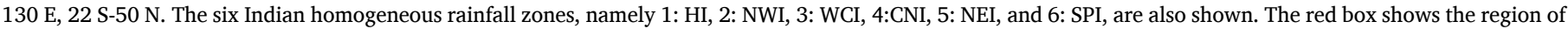
air-sea coupling in ROM. The left and right panel of is the topography used in simulation at $0.22^{\circ}$ and $0.11^{\circ}$. 

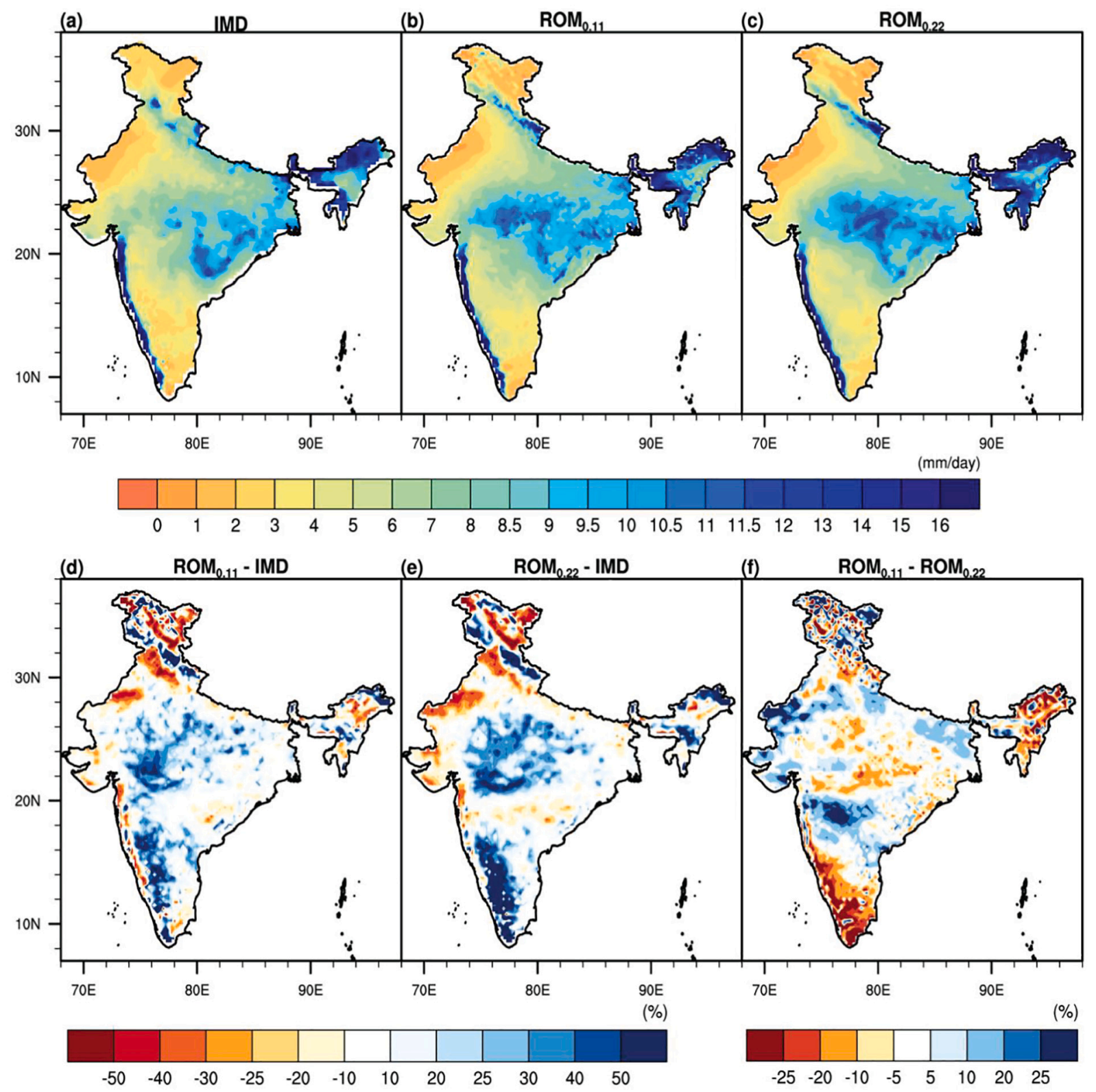

Fig. 2. Seasonal (JJAS) mean rainfall (mm/day) from (a) IMD (b) $\mathrm{ROM}_{0.11}$ and (c) $\mathrm{ROM}_{0.22}$ and biases in percent (model-IMD) (d) ROM $0.11-\mathrm{IMD}_{\text {and }}(\mathrm{e}) \mathrm{ROM} \mathrm{M}_{0.22}-$ IMD and impact of resolution (f) $\left(\mathrm{ROM}_{0.11}-\mathrm{ROM}_{0.22}\right)$.

ROM skill at both resolutions in comparison to RCMs of CORDEX-South Aisa. However, the performance improves in higher resolution $\left(\mathrm{ROM}_{0.11}\right)$. This boosted the confidence in employing our highresolution RESM setup for the future projection of summer monsoon precipitation over India.

In this study, the added value (AV) is defined as the ability to improve (or not) among the two ROM simulations: high-resolution relative to low resolution, as discussed in Karmacharya et al. (2017). Their study justified the direct linkage of added value with the reduction in the magnitude of bias. However, the limitation is sensitivity to the observational data used as reference. This demands high-quality data at fine resolution as a reference as we use high-resolution $25 \mathrm{~km}$ IMD data. It is computed using the following equation:

$\mathrm{AV}=$ Absolute bias in $\mathrm{ROM}_{0.22}-$ Absolute bias in $\mathrm{ROM}_{0.11}$

where Absolute bias in $\mathrm{ROM}_{0 .} 22$ and $\mathrm{ROM}_{0.11}$ is computed as | ROM0.22 - observation| and | ROM0.11 - observation|.

The differences between the $\mathrm{ROM}_{0.22}$ and $\mathrm{ROM}_{0.11}$ simulated precipitation and added value (following Eq. (1)) are computed to highlight the influence of increasing resolution on simulated precipitation. The total impact of shifting from $\mathrm{ROM}_{0.22}$ to $\mathrm{ROM}_{0.11}$ is represented by $\mathrm{ROM}_{0.22}-\mathrm{ROM}_{0.11}$ (Fig. 2f). The figure depicts the decrease in simulated precipitation over CI, WG, and NEI due to increasing resolution. Some patches of increased precipitation are also noticed. In contrast to some previous studies using RCM to investigate the impact of horizontal resolution, which reported either increase (Giorgi and Marinucci, 1996; Bhaskaran et al., 2012) or decrease in precipitation (Karmacharya et al., 2017) or even negligible change (similar bias) (Ashfaq et al., 2009), our study demonstrated mixed nature (increase/decrease) of impact in response to the increasing resolution. Consequently, it resulted in reduced wet and dry bias over the respective regions. Moreover, more value is added over the regions of considerable uncertainty (west-central India and SPI) by reducing the wet bias. Apart from this, we noticed the added value (Fig. S1) of increasing resolution over most Indian land regions except a few small patches where performance is degraded toward increasing resolution. The Positive skill is noticed 
Table 1

Detail description of CORDEX RCMs.

\begin{tabular}{|c|c|c|c|}
\hline $\begin{array}{l}\text { CORDEX } \\
\text { RCMs }\end{array}$ & RegCM & RCA4 & ССMA \\
\hline $\begin{array}{l}\text { RCM } \\
\text { description }\end{array}$ & $\begin{array}{l}\text { The Abdus Salam } \\
\text { International Centre } \\
\text { for Theoretical } \\
\text { Physics (ICTP) } \\
\text { Regional Climatic } \\
\text { Model version } 4\end{array}$ & $\begin{array}{l}\text { Rossby Centre } \\
\text { regional atmospheric } \\
\text { model version } 4\end{array}$ & $\begin{array}{l}\text { Canadian } \\
\text { Centre for } \\
\text { Climate } \\
\text { Modelling }\end{array}$ \\
\hline $\begin{array}{l}\text { Contributing } \\
\text { Modelling } \\
\text { Centre }\end{array}$ & $\begin{array}{l}\text { Centre for Climate } \\
\text { Change Research } \\
\text { (CCCR), Indian } \\
\text { Institute of Tropical } \\
\text { Meteorology } \\
\text { (IITM), India }\end{array}$ & $\begin{array}{l}\text { Rossby Centre, } \\
\text { Swedish } \\
\text { Meteorological and } \\
\text { Hydrological } \\
\text { Institute (SMHI), } \\
\text { Sweden }\end{array}$ & $\begin{array}{l}\text { Canadian } \\
\text { Centre for } \\
\text { Climate } \\
\text { Modelling and } \\
\text { Analysis, } \\
\text { Canada }\end{array}$ \\
\hline Forcings & ERA-Interim & ERA-Interim & ERA-Interim \\
\hline $\begin{array}{l}\text { Horizontal } \\
\text { Resolution }\end{array}$ & $0.44^{\circ} \times 0.44^{\circ}$ & $0.44^{\circ} \times 0.44^{\circ}$ & $0.44^{\circ} \times 0.44^{\circ}$ \\
\hline $\begin{array}{l}\text { Convective } \\
\text { Scheme }\end{array}$ & $\begin{array}{l}\text { Grell over land and } \\
\text { the Emanuel over } \\
\text { the ocean }\end{array}$ & Kain and Fritsch & $\begin{array}{l}\text { mass-flux } \\
\text { closure }\end{array}$ \\
\hline $\begin{array}{l}\text { Land surface } \\
\text { scheme }\end{array}$ & $\begin{array}{l}\text { Community Land } \\
\text { Model version } 3.5\end{array}$ & $\begin{array}{l}\text { Samuelsson et al. } \\
\text { (2006), Dynamic } \\
\text { vegetation model, } \\
\text { LPJ-GUESS }\end{array}$ & $\begin{array}{l}\text { Kowalczyk et al. } \\
\text { (1994) }\end{array}$ \\
\hline $\begin{array}{l}\text { Ensemble- } \\
\text { member }\end{array}$ & r1i1p1 & r1i1p1 & r1i1p1 \\
\hline References & Giorgi et al., 2012 & $\begin{array}{l}\text { Kupiainen et al., } \\
2011\end{array}$ & $\begin{array}{l}\text { Flato et al., } \\
2000\end{array}$ \\
\hline
\end{tabular}

over the region of wet and dry bias in the $\mathrm{ROM}_{0.11}$. The highest skill is noticed over CI and western coast of southern Peninsular India, the region of the more considerable wet bias, and moderate positive skill over the dry bias region of NWI. In contrast to this, some negative skill areas are also noticed, however, the area and magnitude of the negative skill are minimal compared to the regions of positive skill. The patchy pattern in the AV is probably due to the different mechanisms driving the precipitation formation during the summer monsoon. Various studies have reported the different sources of moisture for different subregions of India and different months. A study by Pathak et al. (2017) proposed a more considerable contribution of ocean moisture transport during the first half of the monsoon season, while atmospheric moisture transport contributed mainly in the latter half of the monsoon season. Thus, it will be worthwhile to investigate the temporal evolution of precipitation bias. Fig. 4 depicts the large mean spatiotemporal variability in bias during the monsoon months. The least bias is observed during the initial phase of the monsoon (June), while the maximum is during the withdrawal period (September). The biases are found to be reduced in all months in the $\mathrm{ROM}_{0.11}$ simulation. Lowest/highest bias during the onset/withdrawal phase suggests the possibility of lower/higher uncertainty in ocean/atmospheric moisture transport.

\subsection{Spatiotemporal variability of ISMR}

To assess the advantage of increasing horizontal resolution of ROM in simulating temporal evolution of ISMR, its daily annual cycle over the homogeneous regions of IHMRR is computed with statistical analysis
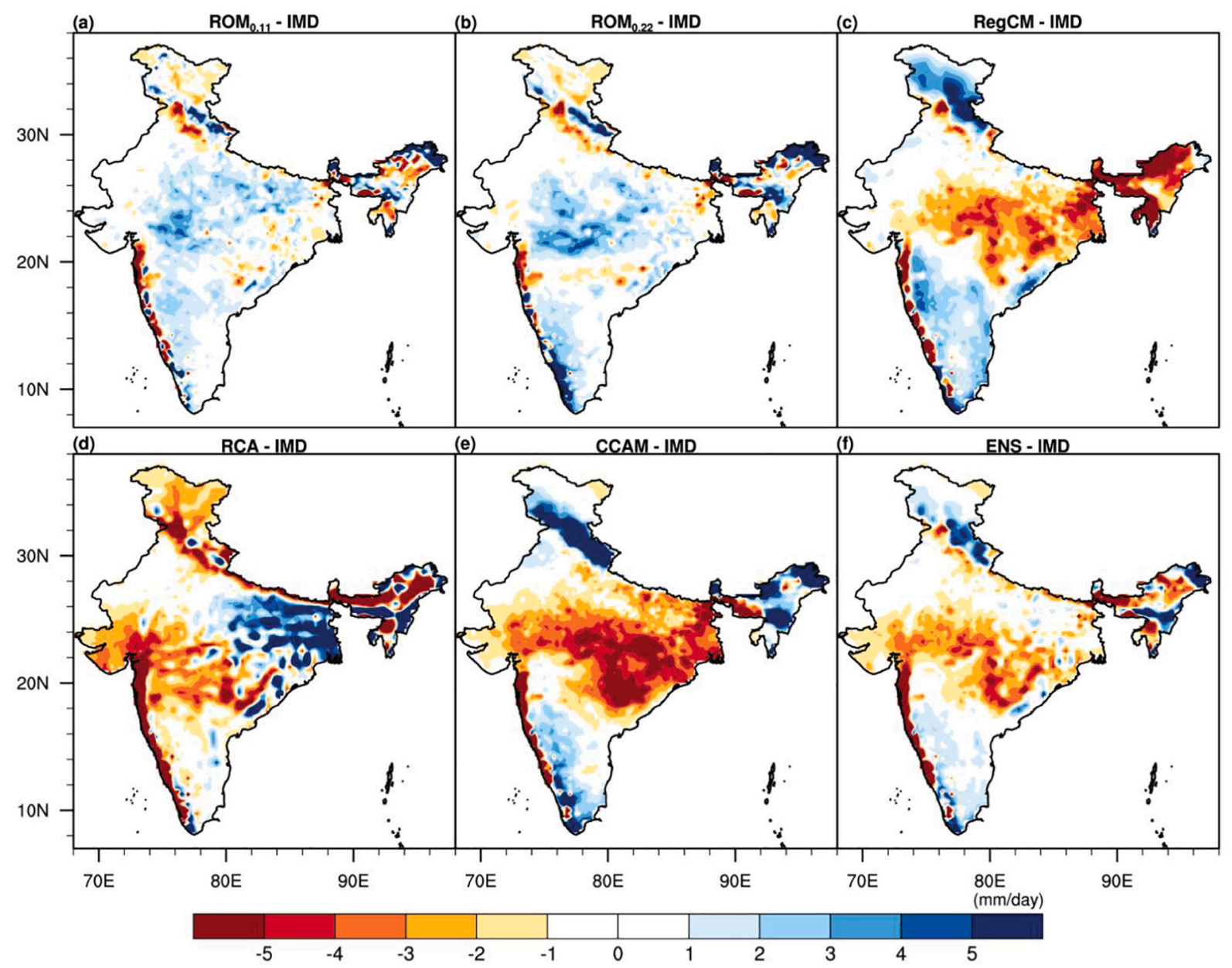

Fig. 3. Seasonal (JJAS) mean rainfall biases (model-IMD): (a) ROM $_{0.11}-$ IMD (b) ROM ${ }_{0.22}-$ IMD (c) RegCM - IMD (d) RCA- IMD (e) CCAM- IMD (f) ENS-IMD. ENS refers to the ensemble mean of RegCM, RCA, and CCAM. 

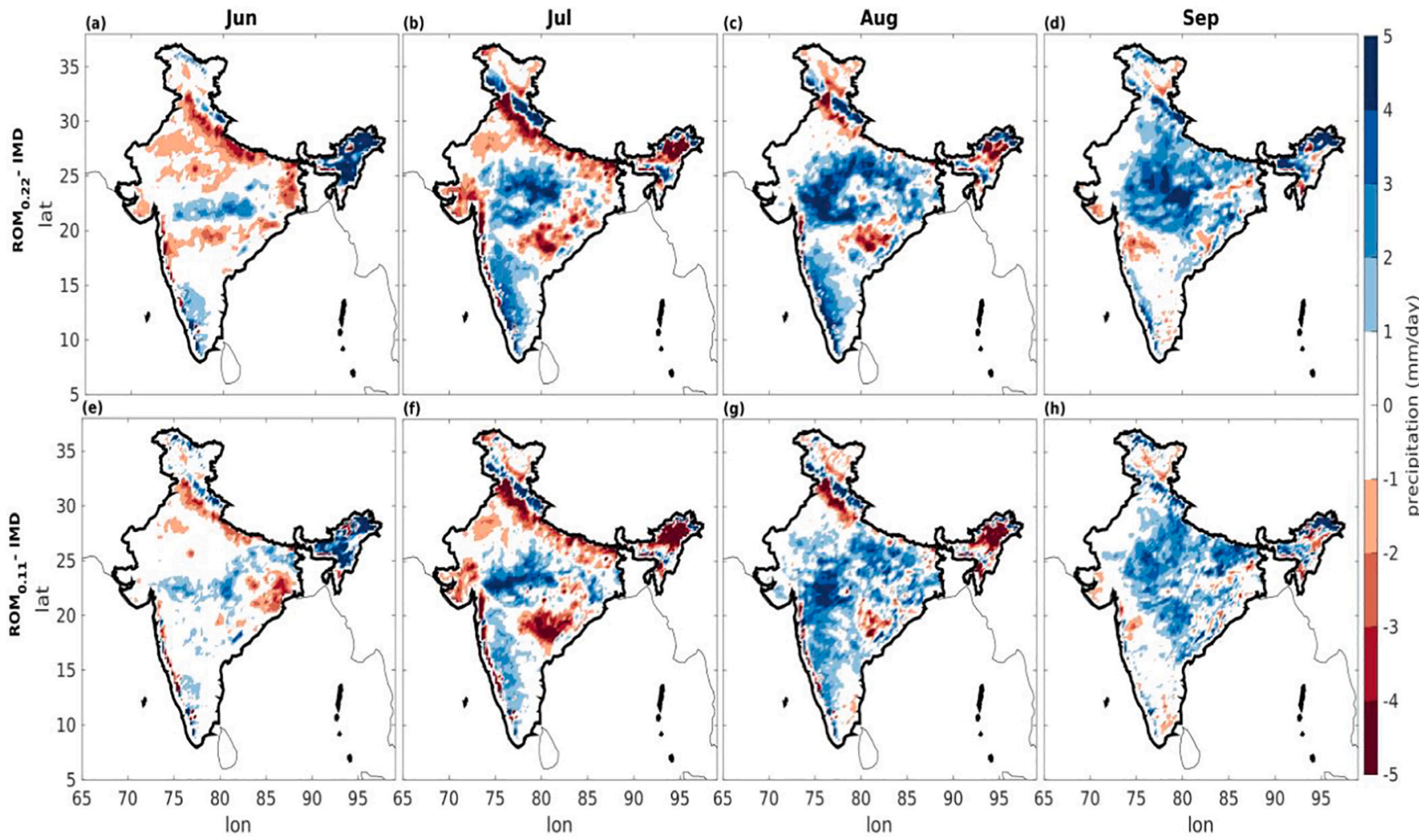

Fig. 4. Monthly rainfall bias (mm/day) $\mathrm{ROM}_{0.22}$ - IMD (upper panel) and $\mathrm{ROM}_{0.11}$ - IMD (lower panel) during June-July-August-September.

and is summarized in Table 2. ROM simulated values closely agree with observations over the homogeneous rainfall zones. We notice that the root mean square error (RMSE) between the model and observation is relatively less than the observed rainfall standard deviation for all zone except SPI, thus demonstrating our simulation's quality as a lesser RMSE of the model than observed variability (standard deviation) is good skill score to measure the quality of the model (Srivastava et al., 2016, 2018; Dwivedi et al., 2018, 2019; Mishra et al., 2020a) Noticeably, the increasing resolution results in improving the model's performance over most of the study regions except SPI where performance is found to degrade with increasing resolution.

The ISM undergoes enhanced and suppressed rainfall activity over India on an intraseasonal time scale (Goswami and Ajaya Mohan, 2001; Dwivedi et al., 2006; Shahi et al., 2018). Past studies using RCM have reported the advantage of high resolution in simulating the intraseasonal variability (ISV) (Dash et al., 2014; Mishra et al., 2020b); however, limited studies have employed a regional coupled atmosphereocean model or RESM to understand mechanisms associated with ISV (Misra et al., 2017; Di Sante et al., 2019). Therefore, it would be interesting to demonstrate the ROM simulation's fidelity in reproducing the ISV. The convective bands of eastward and northward propagation over

Table 2

Root mean square (RMSE) and standard deviation are shown as performance evaluation of $\mathrm{ROM}_{0.22}$ and $\mathrm{ROM}_{0.11}$ over the six Indian homogeneous rainfall zones for daily climatological precipitation.

\begin{tabular}{|c|c|c|}
\hline \multirow[t]{2}{*}{ Zone } & $\underline{\mathrm{ROM}_{0.22} / \mathrm{ROM}_{0.11}}$ & \multirow[t]{2}{*}{ Observation (standard deviation) } \\
\hline & RMSE & \\
\hline CNI & $1.73 / 1.71$ & 2.25 \\
\hline NWI & $1.38 / 1.31$ & 2.23 \\
\hline NEI & $2.25 / 2.09$ & 2.07 \\
\hline WCI & $1.57 / 155$ & 2.56 \\
\hline SPI & $1.24 / 1.8$ & 0.83 \\
\hline HI & $1.58 / 1.46$ & 1.48 \\
\hline
\end{tabular}

the equatorial Indian Ocean (EIO) and Indian Ocean (IO) significantly modulate the ISV of ISMR (Sperber and Annamalai, 2008; Yasunari, 1980; Webster et al., 1998; Sabeerali et al., 2013). It will be noteworthy to illustrate the effect of horizontal resolution in simulating the eastward and northward propagation. We employed the methodology of Sabeerali et al. (2013) to compute these propagating bands. The propagation of eastward and northward convection is computed by regressing the 20-100 day bandpass filtered precipitation for both propagation modes at each grid against a reference time series. The reference time series is computed as the averaged $20-100$ day filtered precipitation over the region $12^{\circ} \mathrm{N}-22^{\circ} \mathrm{N}$ and $70^{\circ} \mathrm{E}-90^{\circ} \mathrm{E}$ for the northward propagation and over $10^{\circ} \mathrm{S}-5^{\circ} \mathrm{N}$ and $75^{\circ} \mathrm{E}-100^{\circ} \mathrm{E}$ for the eastward propagation. Fig. S2 shows the lag-longitude map averaged over $5^{\circ} \mathrm{S}-5^{\circ} \mathrm{N}$ concerning the eastward propagation. Similarly, a lag-latitude map averaged over $70^{\circ} \mathrm{E}-95^{\circ} \mathrm{E}$ for the northward propagation is shown in Fig. 5. It is observed that ROM has the potential to reproduce these eastward and northward propagation bands realistically when compared to observations. Further, ROM performs much better compared to other CORDEXSouth Asia RCMs (Fig. 5). The figure also depicts a clear improvement in the representation of the eastward and northward propagation of waves over the equatorial IO toward increasing resolution. This improved representation of the eastward and northward propagating bands toward increasing resolution may be one of the possible causes of reduced uncertainty in JJAS mean precipitation in $\mathrm{ROM}_{0.11}$.

\subsection{Identification of source of bias in seasonal mean precipitation}

Earlier studies have shown the relative contribution of convective scale (CS) and large scale (LS) precipitation during JJSA season on convective events have a stochastic nature (Ahmed et al., 2015). The result of CS and LS precipitation and their partitioning are governed by the parameterization schemes available in the model (He and Alapaty, 2018). Therefore, it is worthwhile to investigate the potential of ROM simulations at the different horizontal resolutions to produce CS and LS 

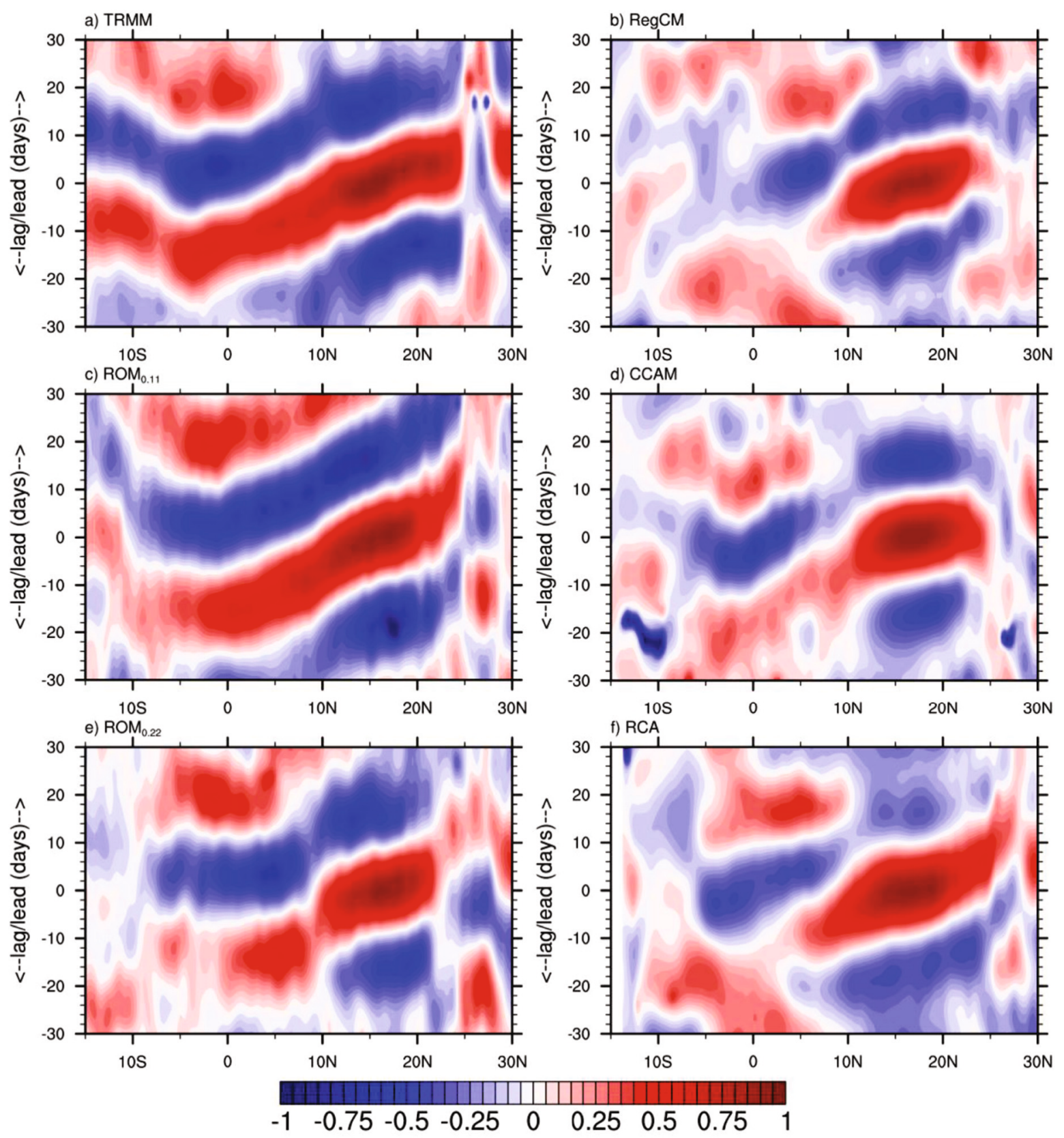

Fig. 5. Northward propagation: Lag-latitudes regressed anomalies of 20-100 days bandpass filtered precipitation (shaded; mm/day) band with reference time series averaged for a box over the Tropical Indian Ocean $\left(10^{\circ} \mathrm{S}-5^{\circ} \mathrm{N}\right.$ to $\left.75^{\circ} \mathrm{E}-100^{\circ} \mathrm{E}\right)$.

precipitation and quantify their dominance toward total precipitation biases. Fig. 6 indicates the JJAS season mean CS and LS precipitation. The total precipitation mean bias in both simulations $\left(\mathrm{ROM}_{0.22}\right.$ and $\mathrm{ROM}_{0.11}$ ) closely resembles LS mean precipitation. Especially, the regions of sizeable wet precipitation bias over WCI are co-located with the regions of LS precipitation, suggesting that the wet bias in total precipitation is mainly from the uncertainty in the LS precipitation. It is interesting to note that the LS shows greater sensitivity to horizontal resolution in comparison to CS.

The strength of the Indian monsoon is significantly affected by the sea surface temperature (SST) of the IO (Srivastava et al., 2018; Mishra et al., 2020a). Therefore, the comparative skill of the ROM in representing the IO SST is worth mentioning. However, in both ROM setups, the ocean model has the same horizontal resolution; the only changes, $0.22^{\circ}$ to $011^{\circ}$, are in RCM REMO. So whatever effect we see here is the impact of atmosphere-ocean coupling feedbacks. ROM is able to distinguish the regions of low and high SST when compared to observations (Fig. 7). However, the ROM at both resolutions shows a systematic warm/cold bias affecting the monsoon precipitation simulation. For example, a strong warm bias $\left(\sim 1-2{ }^{\circ} \mathrm{C}\right)$ is noticed along with the Somalia-Oman upwelling region. This unrealistic warming over the western AS may be possibly associated with reduced upwelling. This anomalous warming is attributed to the weaker zonal SST gradient over the AS, leading to weaker southwesterly winds, which should scientifically diminish the moisture supply toward India (Roxy et al., 2015). Increasing horizontal resolution has minimal impact on reducing uncertainty.

The lower and upper-level circulations are one of the large-scale 

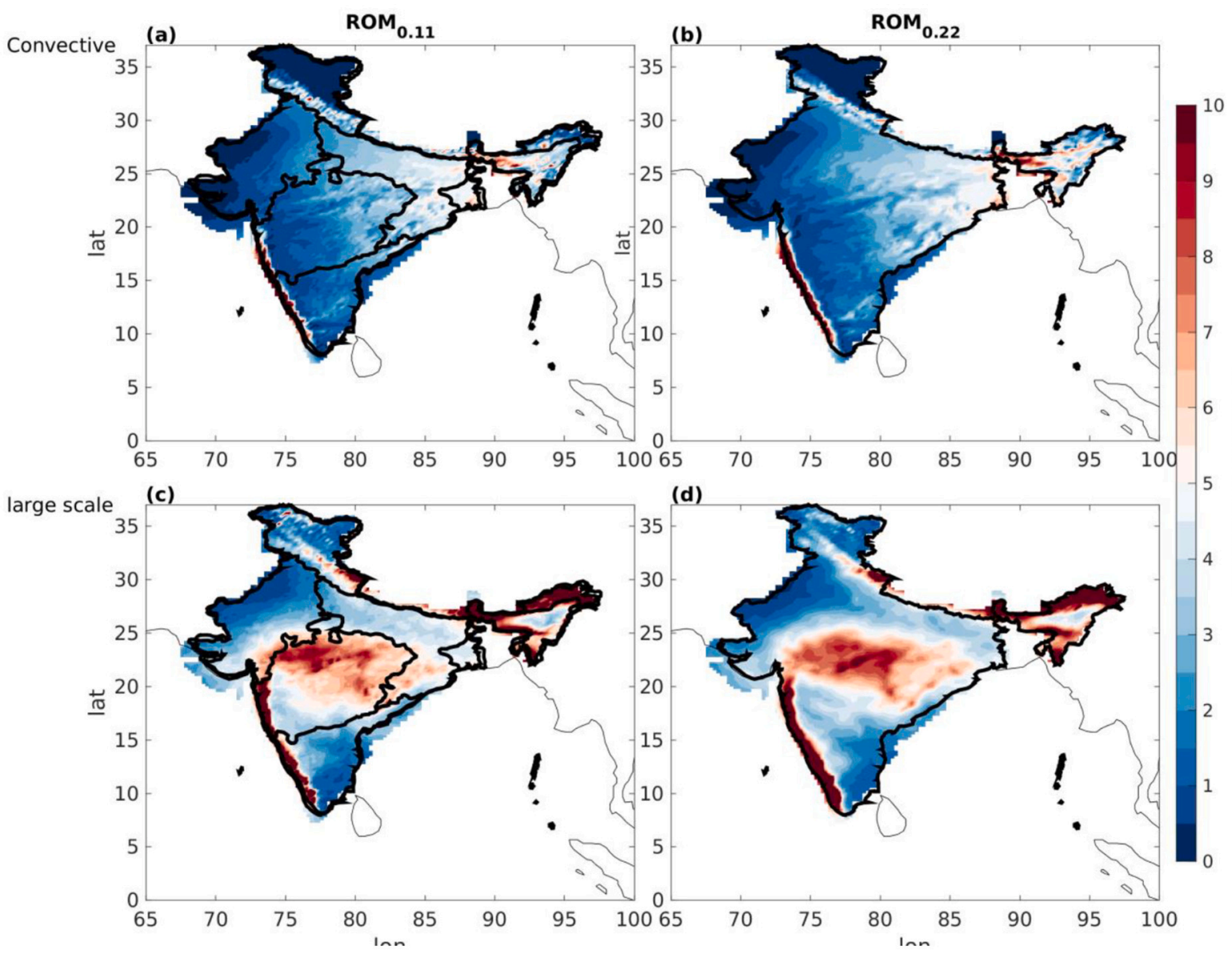

Fig. 6. JJAS averaged convective precipitation (a) ROM 0.11 and (b) ROM 0.22. Similarly (c) and (d) for large-scale precipitation.
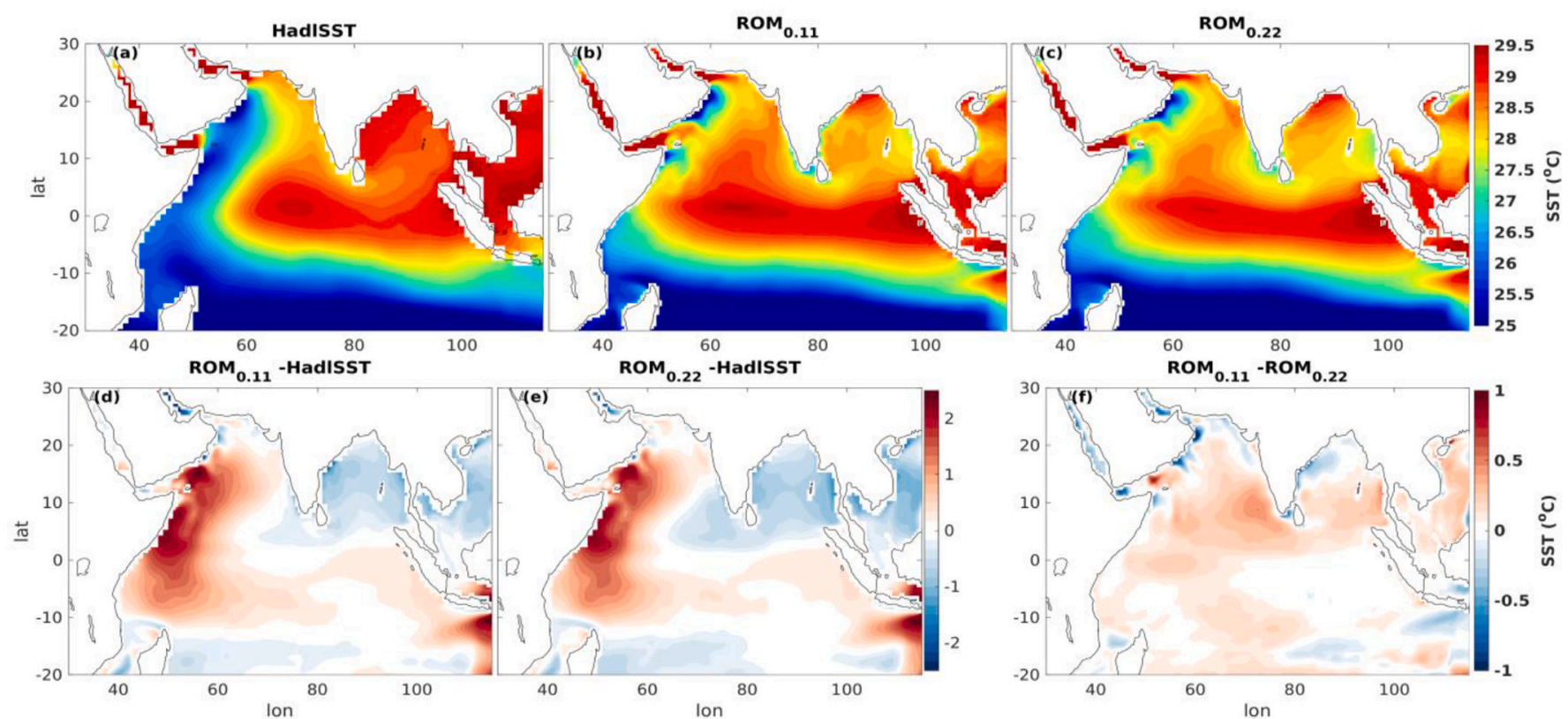

Fig. 7. Seasonal (JJAS) mean SST ( ${ }^{\circ} \mathrm{C}$ ) from (a) HadSST (b) $\mathrm{ROM}_{0.11}$ and (c) $\mathrm{ROM}_{0.22}$ and biases (model-Had SST) (d) $\mathrm{ROM}_{0.11}-\mathrm{HadSST}_{\text {and }}$ (e) ROM $\mathrm{RO}_{0.22}-\mathrm{HadSST}$ and impact of resolution (f) $\mathrm{ROM}_{0.11}-\mathrm{ROM}_{0.22}$.

dynamic features that significantly control the strength of ISMR over India (Joseph and Raman, 1996; Findlater, 1969). Therefore, it is crucial to investigate the impact of horizontal resolution in simulating the low- level circulation. The location of the core of the low-level jet (LLJ), Tropical Easterly Jet, and Subtropical Westerly Jet is found to be well simulated by ROM at both resolutions (Figure not shown). Fig. 8 
represents the bias map depicting the underestimation of the strength of LLJ across the location of the core of LLJ in both simulations (ROM0.22 and ROM0.11), which is consistent with warm SST bias over the Somalia-Oman upwelling region. This is in conformity with the study by Mishra et al. (2020a) reporting the weakening of the LLJ due to AS warming. The overestimation of southwesterly over northern AS is also observed, which may be due to the somewhat northward shifting of the LLJ. Apart from this, we noticed the stronger southerly wind from the equatorial Indian ocean entering to southern Indian, facilitating the anomalous moisture supply over southern India and enhanced the precipitation.

A similar spatial pattern of bias persists in $\mathrm{ROM}_{0.11}$ (Fig. 8b), however, it shows a slight reduction in the wind speed over southern AS, Bay of Bengal (BoB), and India. The reduction of wind speed over the Indian land region reduces evapotranspiration and hence local moisture, leading to reduced wet bias. Apart from this, the weakening of the southerly from the equatorial region along the southernmost tip of India toward southern India and south-westerly over AS compared to $\mathrm{ROM}_{0.22}$ is consistent with the reduction in the wet bias in $\mathrm{ROM}_{0.11}$. The weak monsoon circulation may contribute to the suppression of moisture transport from AS to the Indian land region, which is also noted in the vertically integrated moisture flux map (Fig. 9). This suggests that the contribution of moisture from oceanic sources is not attributed to the land wet bias in the ROM at both resolutions. This persistent wet bias may be related to the local recycling moisture, demanding a further investigation to diagnose the source of excess moisture for precipitation, particularly in LS. This is in conformity with the previous study by Pathak et al. (2019), who observed a greater contribution of LS precipitation uncertainty arising from the atmospheric component, especially in August and September and when the ocean moisture contributes the maximum during the initial phase of ISMR, i.e., June-July. This uneven contribution of moisture transport from different sources is also apparent in the monthly bias maps (Fig. 4).

A study by Goswami and Xavier (2005) indicates that the land-ocean thermal contrast is the basic initial driver of the ISMR while tropospheric temperature (TT) (vertically averaged between 200 and $600 \mathrm{hPa}$ ) is an important thermodynamic driver for sustaining the monsoon strength and controlling the onset, withdrawal, and length of the ISM season. Both ROM model simulations reproduce the mean features of the TT reasonably well (Fig. S3). However, the values are overestimated, particularly over the Tibetan plateau, leading to a stronger TT gradient resulting in the convergence of the moist static energy facilitating the favourable condition for the occurrence of convective events due to enhanced atmospheric instability (Pandey et al., 2020). Therefore, this warm bias may be attributed to the wet bias in ROM. The relative reduction in the warm bias with increasing horizontal resolution is also consistent with the reduction of wet bias.
The vertical heating profile significantly governs the precipitation over the region by affecting atmospheric stability. For example, the slower/faster rate of warming of the mid-troposphere than that of the lower levels decreases/increases atmospheric stability and hence strengthens/weakens precipitation (Cao et al., 2012). We diagnose atmospheric stability by computing a metric based on the difference of air temperature $(\Delta \mathrm{AT})$ in the mid-troposphere $(700 \mathrm{hPa})$ and lower atmosphere $(925 \mathrm{hPa})$, which has been used previously by Pandey et al. (2020). The $\Delta$ AT of both simulations is subtracted from the corresponding reanalysis for determining the relative difference between the model and the observations. Fig. 10a and b depict that the ROM at both resolutions tends to produce higher (lower) atmospheric stability than that produced by EIN over WCI, WG (SPI, eastern central India, and northern India). The increasing/decreasing atmospheric stability results in weakening/strengthening of convective activity over these regions, leading to weaker/stronger availability of moisture supply for suppressed/enhanced precipitation over the region. Thus, the observed wet/dry bias in ROM can be attributed to the lower/higher atmospheric stability in the model. It is also seen that $\mathrm{ROM}_{0.11}$ produces relatively higher stability than that produced by $\mathrm{ROM}_{0.22}$ over WCI, which is consistent with the reduction of wet bias.

We also observe stronger specific humidity in ROM's simulations than in that of observation, particularly over regions having wet bias (Fig. 10c, d), which could be associated with the overestimation of wind speed over the same region along with warmer temperature bias that further enhances the moisture-holding capacity of air. The warm bias is partially associated with the incorrect partitioning of the radiative energy: an imbalanced Bowen ratio (Figure not shown). The larger part of the received radiative energy at the surface is used to increase the temperature. Similarly, weaker specific humidity than that in observation is also noticed over the regions having underestimation of precipitation. Barring few places, the higher/lower specific humidity is colocated with wet/dry bias regions.

\section{Conclusions}

For the first time over the CORDEX-South Asia region, ROM is applied to investigate the influence of the horizontal resolution on the simulation of the Indian summer monsoon rainfall and associated dynamical and thermodynamical processes. After the model spinup, simulations were performed with ROM with the same oceanic but at two different horizontal atmospheric resolutions: $\operatorname{ROM}_{0.22}(\sim 25 \mathrm{~km})$ and $\mathrm{ROM}_{0.11}(\sim 12 \mathrm{~km})$ for 38 years. The skill of both simulations is assessed against available observations. It is observed that ROM at both resolutions performs remarkably well in simulating the mean precipitation and variability. The improved mean simulation of precipitation enhances the confidence for future advancement toward the improved simulation of
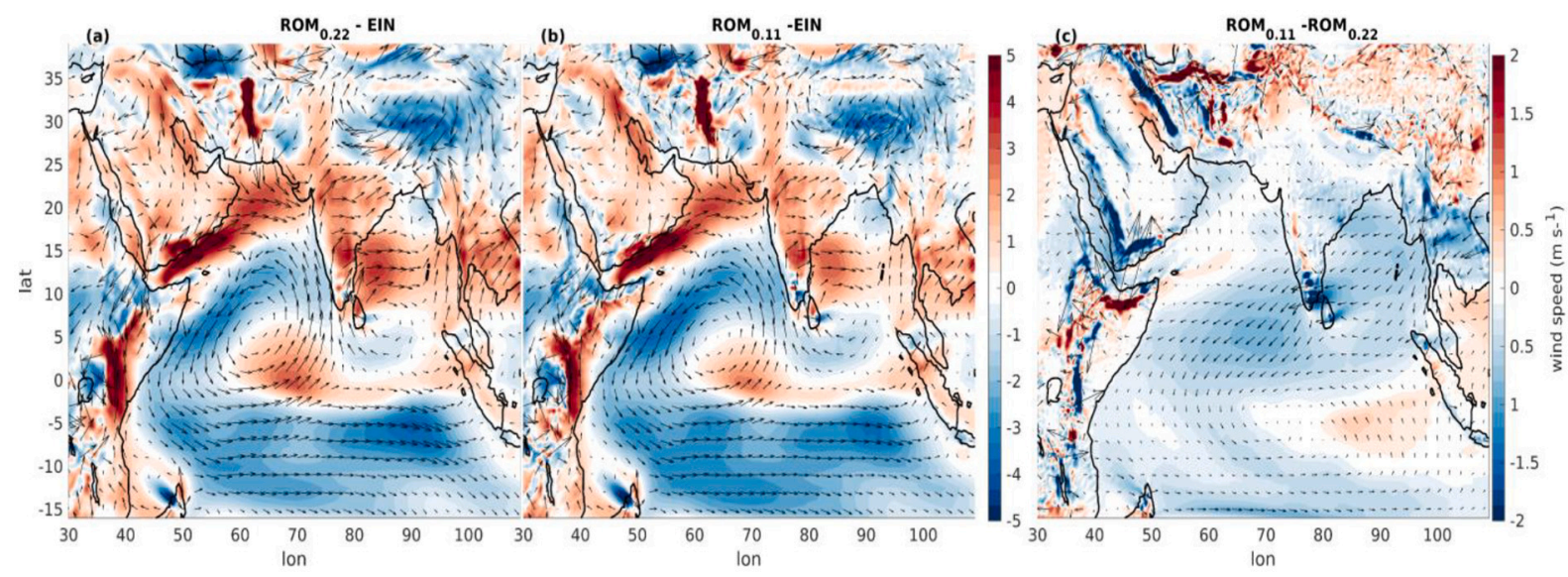

Fig. 8. Seasonal (JJAS) mean wind bias at $850 \mathrm{hPa}$ (a) $\mathrm{ROM}_{0.11}-\mathrm{EIN}$ and (b) $\mathrm{ROM}_{0.22}-\mathrm{EIN}$ and impact of air-sea coupling, (c) ROM $0.11-\mathrm{ROM}_{0.22}$. 

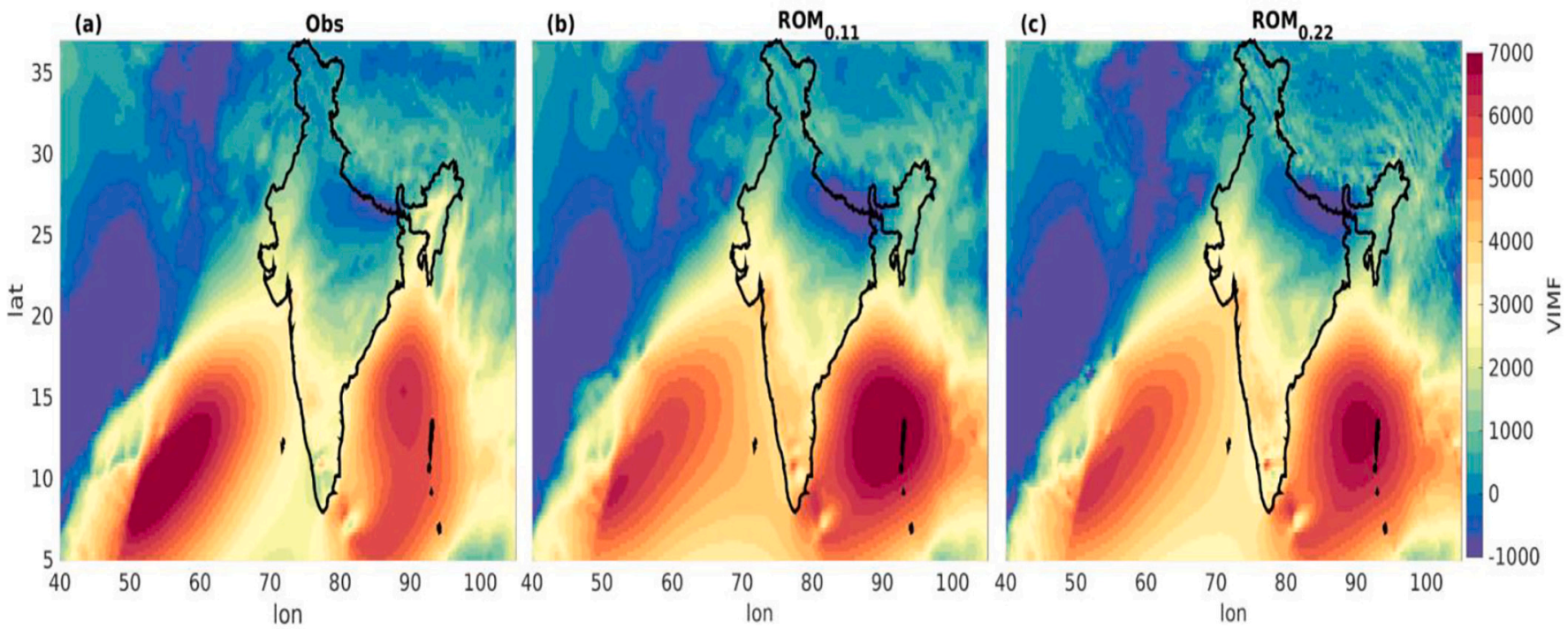

Fig. 9. Seasonal (JJAS) mean vertically integrated moisture flux (kg m-1 s-1) from (a) EIN (b) ROM0.11 and (c) ROM0.22.
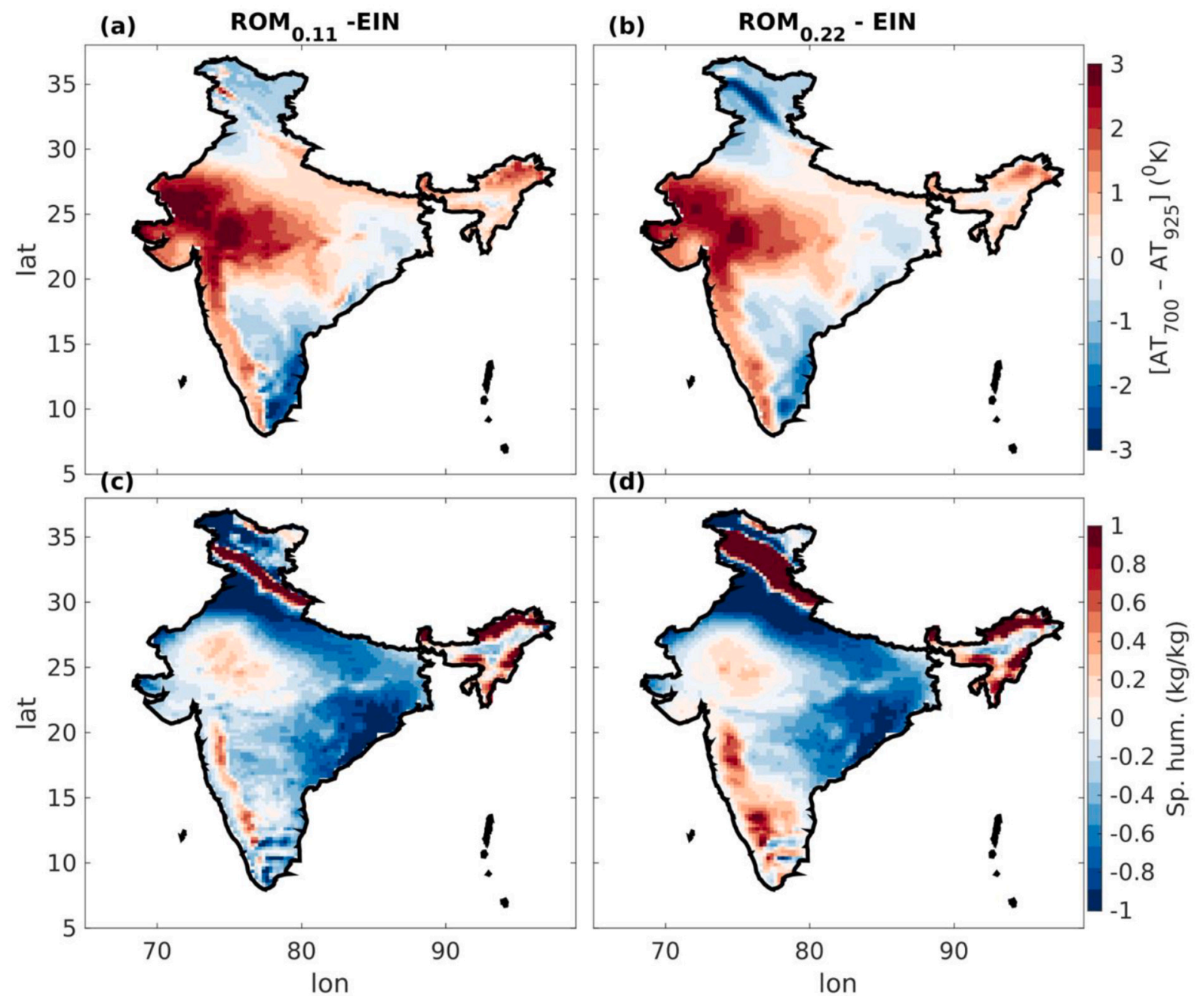

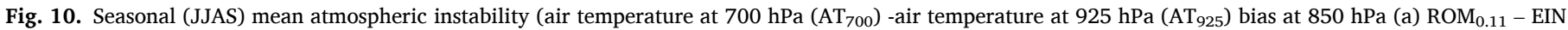
and (b) $\mathrm{ROM}_{0.22}$ - EIN and impact of air-sea coupling (c) $\mathrm{ROM}_{0.11}-\mathrm{ROM}_{0.22}$. The lower panel is similar to the upper panel but for specific humidity. 
ISMR. In general, the wet/dry bias over India is mostly associated with the overestimation/underestimation of the LS/CS component of precipitation. Increasing horizontal resolution from $25 \mathrm{~km}$ to $12 \mathrm{~km}$ improves the simulation of JJAS mean precipitation by reducing the wet/ dry bias over WCI and southern peninsular India (eastern $\mathrm{CI}$ ). The reduction in wet bias is mostly associated with suppression/enhancement of the LS/CS precipitation. This improvement in mean precipitation is partially due to the improved representation of the eastward and northward propagation of convective bands. Despite the above improvements, the wet precipitation bias, particularly over western CI, is persistent. It is interesting to note that the bias exhibits strong spatiotemporal heterogeneity, which may be contributed to by the different moisture transport sources. It has been reported that the ocean serves as the primary contributor of moisture for precipitation during the initial phase of the monsoon season, while atmospheric moisture largely contributes after the peak monsoon month (July) (Pathak et al., 2019). Therefore, the source of bias is suspected to originate from the ocean and atmosphere. The weaker Findlater jet associated with weaker landocean thermal contrast caused by the warm SST bias over the western AS may contribute to the suppression of moisture transport from AS to the Indian land region. The wet bias is associated with the favourable atmospheric condition (instability) and enhanced moisture availability due to increased specific humidity over India that could be associated with the overestimation of wind speed over the same region along with warmer temperature bias, which further enhances the moisture-holding capacity of air.

The poor representation of recycling rate due to weak interactive land-atmosphere coupling in ROM's setup may also lead to limited energy and moisture exchange from land to the atmosphere or vice-versa. Further in-depth mechanisms needed to investigate the different oceanic and terrestrial contributors of sources of moisture transport associated with the wet bias lie beyond the scope of the present paper. Our future study will be focused on identifying oceanic and terrestrial contributors to sources of moisture transport and their relationship to the rainfall over different homogeneous regions of India.

\section{Data availability statement}

The observational datasets used in this study are derived from public resources, and model data would be made available upon request to the corresponding author.

\section{Authors declaration}

Alok Kumar Mishra contributed to conceptualization, data curation, formal analysis, methodology, writing the original draft. Pankaj Kumar contributed to conceptualization, resources, funding acquisition, supervision and writing, Aditya Kumar Dubey, Aaquib Javed and Md Saquib Saharwardi contributed to data curation. Dimitry V. Sein contributed to model simulation. Daniela Jacob resources. All authors have contributed to reviewing and editing the manuscript.

\section{Declaration of Competing Interest}

The authors declare that they have no known competing financial interests or personal relationships that could have appeared to influence the work reported in this paper.

\section{Acknowledgement}

We thank the anonymous reviewers for their constructive comments and suggestions, which have helped us improve the overall quality of the paper. This work is jointly supported by the Department of Science and Technology (DST), Govt. of India, grant number DST/INT/RUS/RSF/P33/G, and the Russian Science Foundation (Project No.: 19-47-02015). PK acknowledges funding from the Science and Engineering Research
Board (SERB), Govt. of India grant number SB/S2/RJN-080/2014, and Department of Science and Technology (DST) grant number DST/CCP/ NCM/69/2017(G). MSS acknowledges DST for providing INSPIRE fellowship (IF160281). The authors are thankful to the respective agencies of the IMD, ECMWF ERA-Interim, and HadISST data products for making available these datasets. 'Dmitry V. Sein and Stanislav D. Martyanov worked in the framework of the state assignment of the Ministry of Science and Higher Education of Russia (No 0128-20210014). This work used resources of the Deutsches Klimarechenzentrum (DKRZ) granted by its Scientific Steering Committee (WLA) under project ID ba1144. The dynamically downscaled CORDEX RCMs data are obtained from the Centre for Climate Change Research (CCCR), Indian Institute of Tropical Meteorology (IITM). The authors declared that the manuscript contents are novel and neither published nor under consideration anywhere else. The authors also declared that they have no known financial interest.

\section{Appendix A. Supplementary data}

Supplementary data to this article can be found online at https://doi. org/10.1016/j.atmosres.2021.105681.

\section{References}

Ahmed, F., Schumacher, C., Ahmed, F., Schumacher, C., 2015. Convective and stratiform components of the precipitation-water vapor relationship. AGUFM 2015, A53I-02.

Aldrian, E., Sein, D., Jacob, D., Gates, L.D., Podzun, R., 2005. Modelling Indonesian rainfall with a coupled regional model. Clim. Dyn. 25, 1-17. https://doi.org/ 10.1007/s00382-004-0483-0.

Ashfaq, M., Shi, Y., Tung, W.W., Trapp, R.J., Gao, X., Pal, J.S., Diffenbaugh, N.S., 2009. Suppression of south Asian summer monsoon precipitation in the 21st century. Geophys. Res. Lett. 36 https://doi.org/10.1029/2008GL036500.

Barker, H.W., Cole, J.N.S., Li, J., von Salzen, K., 2016. A parametrization of 3-D subgridscale clouds for conventional GCMs: assessment using A-Train satellite data and solar radiative transfer characteristics. J. Adv. Model. Earth Syst. 8, 566-597. https://doi. org/10.1002/2015MS000601.

Bhaskaran, B., Ramachandran, A., Jones, R., Moufouma-Okia, W., 2012. Regional climate model applications on sub-regional scales over the Indian monsoon region: The role of domain size on downscaling uncertainty. J. Geophys. Res. Atmos. 117 https://doi.org/10.1029/2012JD017956 n/a-n/a.

Bhatla, R., Verma, S., Ghosh, S., Mall, R.K., 2020. Performance of regional climate model in simulating Indian summer monsoon over Indian homogeneous region. Theor. Appl. Climatol. 139, 1121-1135. https://doi.org/10.1007/s00704-019-03045-x.

Byrne, D., Munnich, M., Frenger, I., Gruber, N., Byrne, D., Munnich, M., Frenger, I., Gruber, N., 2016. Mesoscale atmosphere-ocean coupling enhances the transfer of wind energy into the ocean. AGUOS 2016 (PO12D-07).

Cabos, W., Sein, D.V., Durán-Quesada, A., Liguori, G., Koldunov, N.V., MartínezLópez, B., Alvarez, F., Sieck, K., Limareva, N., Pinto, J.G., 2019. Dynamical downscaling of historical climate over CORDEX Central America domain with a regionally coupled atmosphere-ocean model. Clim. Dyn. 52, 4305-4328. https:// doi.org/10.1007/s00382-018-4381-2.

Cabos, W., de la Vara, A., Álvarez-García, F.J., Sánchez, E., Sieck, K., Pérez-Sanz, J.I., Limareva, N., Sein, D.V., 2020. Impact of ocean-atmosphere coupling on regional climate: the Iberian Peninsula case. Clim. Dyn. 54, 4441-4467. https://doi.org/ 10.1007/s00382-020-05238-x.

Cao, L., Bala, G., Caldeira, K., 2012. Climate response to changes in atmospheric carbon dioxide and solar irradiance on the time scale of days to weeks. Environ. Res. Lett. 7 (3), 034015.

Cha, D.-H., Jin, C.-S., Moon, J.-H., Lee, D.-K., 2016. Improvement of regional climate simulation of East Asian summer monsoon by coupled air-sea interaction and largescale nudging. Int. J. Climatol. 36, 334-345. https://doi.org/10.1002/joc.4349.

Chan, S.C., Kendon, E.J., Fowler, H.J., Blenkinsop, S., Ferro, C.A.T., Stephenson, D.B., 2013. Does increasing the spatial resolution of a regional climate model improve the simulated daily precipitation? Clim. Dyn. 41, 1475-1495. https://doi.org/10.1007/ s00382-012-1568-9.

Charney, J.G., Shukla, J., 1981. Predictability of monsoon. In: Lighthill, J., Pearce, R.P. (Eds.), Monsoon Dynamics. Cambridge University Press, pp. 99-110.

Chaudhari, H.S., Pokhrel, S., Saha, S.K., Dhakate, A., Yadav, R.K., Salunke, K., Mahapatra, S., Sabeerali, C.T., Rao, S.A., 2013. Model biases in long coupled runs of NCEP CFS in the context of Indian summer monsoon. Int. J. Climatol. 33, 1057-1069. https://doi.org/10.1002/joc.3489.

Collins, M., Minobe, S., Barreiro, M., Bordoni, S., Kaspi, Y., Kuwano-Yoshida, A., Keenlyside, N., Manzini, E., O’Reilly, C.H., Sutton, R., Xie, S.P., Zolina, O., 2018. Challenges and opportunities for improved understanding of regional climate dynamics. Nat. Clim. Chang. 8, 101-108. https://doi.org/10.1038/s41558-0170059-8.

Dash, S.K., Pattnayak, K.C., Panda, S.K., Vaddi, D., Mamgain, A., 2014. Impact of domain size on the simulation of Indian summer monsoon in RegCM4 using mixed 
convection scheme and driven by HadGEM2: impact of domain size on ISM simulations. Clim. Dyn. 44, 961-975. https://doi.org/10.1007/s00382-014-2420-1.

Dee, D.P., Uppala, S.M., Simmons, A.J., Berrisford, P., Poli, P., Kobayashi, S., Andrae, U., Balmaseda, M.A., Balsamo, G., Bauer, P., Bechtold, P., Beljaars, A.C.M., van de Berg, L., Bidlot, J., Bormann, N., Delsol, C., Dragani, R., Fuentes, M., Geer, A.J., Haimberger, L., Healy, S.B., Hersbach, H., Hólm, E.V., Isaksen, L., Kållberg, P., Köhler, M., Matricardi, M., Mcnally, A.P., Monge-Sanz, B.M., Morcrette, J.J., Park, B K., Peubey, C., de Rosnay, P., Tavolato, C., Thépaut, J.N., Vitart, F., 2011. The ERAInterim reanalysis: Configuration and performance of the data assimilation system. Q. J. R. Meteorol. Soc. 137, 553-597. https://doi.org/10.1002/qj.828.

Di Sante, F., Coppola, E., Farneti, R., Giorgi, F., 2019. Indian Summer Monsoon as simulated by the regional earth system model RegCM-ES: the role of local air-sea interaction. Clim. Dyn. 53, 759-778. https://doi.org/10.1007/s00382-019-04612-8.

Dwivedi, S., Mittal, A.K., Goswami, B.N., 2006. An empirical rule for extended range prediction of duration of Indian summer monsoon breaks. Geophys. Res. Lett. 33 https://doi.org/10.1029/2006GL027035 n/a-n/a.

Dwivedi, S., Srivastava, A., Mishra, A.K., 2018. Upper-ocean four-dimensional variational data assimilation in the Arabian Seaand Bay of Bengal. Mar. Geod. 41 (3), 230-257.

Dwivedi, S., Mishra, A.K., Srivastava, A., 2019. Upper Ocean high resolution regional modeling of the Arabian Sea and Bay of Bengal. Acta Oceanol. Sin. 38, 32-50. https://doi.org/10.1007/s13131-019-1439-x.

Eyring, V., Bony, S., Meehl, G.A., Senior, C.A., Stevens, B., Stouffer, R.J., Taylor, K.E., 2016. Overview of the coupled Model Intercomparison Project phase 6 (CMIP6) experimental design and organization. Geosci. Model Dev. 9, 1937-1958. https:// doi.org/10.5194/gmd-9-1937-2016.

Findlater, J., 1969. A major low-level air current near the Indian Ocean during the northern summer. Q. J. R. Meteorol. Soc. 95, 362-380. https://doi.org/10.1002/ qj. 49709540409.

Flato, G.M., Boer, G.J., Lee, W.G., McFarlane, N.A., Ramsden, D., Reader, M.C., Weaver, A.J., 2000. The Canadian centre for climate modelling and analysis global coupled model and its climate. Clim. Dyn. 16, 451-467. https://doi.org/10.1007/ s003820050339.

Fu, X., Wang, B., Li, T., 2002. Impacts of air-sea coupling on the simulation of mean Asian summer monsoon in the ECHAM4 model. Mon. Wea. Rev. 130, 2889-2904.

Fu, X., Wang, B., Waliser, D.E., Tao, L., 2007. Impact of atmosphere-ocean coupling on the predictability of monsoon intraseasonal oscillations. J. Atmos. Sci. 64, 157-174. https://doi.org/10.1175/JAS3830.1.

Giorgi, F., Marinucci, M.R., 1996. A investigation of the sensitivity of simulated precipitation to model resolution and its implications for climate studies. Mon Weather Rev. 24 (1), 148-166.

Giorgi, F., Coppola, E., Solmon, F., Mariotti, L., Sylla, M.B., Bi, X., Elguindi, N., Diro, G. T., Nair, V., Giuliani, G., Turuncoglu, U.U., 2012. RegCM4: model description and preliminary tests over multiple CORDEX domains. Clim. Res. 52, 7-29.

Goswami, B.N., 2005. South Asian monsoon. In: Lau, W.K.M., Waliser, D.E. (Eds.), Intraseasonal Variability of the Atmosphere-ocean Climate System. Springer, Berlin, Heidelberg, pp. 19-61.

Goswami, B.N., Ajaya Mohan, R.S., 2001. Intraseasonal oscillations and interannual variability of the Indian summer monsoon. J. Clim. 14, 1180-1198. https://doi.org/ 10.1175/1520-0442(2001)014<1180:IOAIVO>2.0.CO;2.

Goswami, B.N., Xavier, P.K., 2005. Dynamics of internal interannual variability of the Indian summer monsoon in a GCM. J. Geophys. Res. 110, D24104 https://doi.org/ 10.1029/2005JD006042.

Hack, J.J., Caron, J.M., Danabasoglu, G., Oleson, K.W., Bitz, C., Truesdale, J.E., 2006. CCSM-CAM3 climate simulation sensitivity to changes in horizontal resolution. J. Clim. 19, 2267-2289. https://doi.org/10.1175/JCLI3764.1.

Hagemann, S., Dümenil, L., 1997. A parametrization of the lateral waterflow for the global scale. Climate Dynamics 14, 17-31. https://doi.org/10.1007/s00382005020

He, J., Alapaty, K., 2018. Precipitation partitioning in multiscale atmospheric simulations: impacts of stability restoration methods. J. Geophys. Res. Atmos. 123, 10,185-10,201. https://doi.org/10.1029/2018JD028710.

Jacob, D., 2001. A note to the simulation of the annual and inter-annual variability of the water budget over the Baltic Sea drainage basin. Meteorog. Atmos. Phys. 77, 61-73. https://doi.org/10.1007/s007030170017.

Jacob, D., Elizalde, A., Haensler, A., Hagemann, S., Kumar, P., Podzun, R., Rechid, D., Remedio, A.R., Saeed, F., Sieck, K., Teichmann, C., Wilhelm, C., 2012. Assessing the transferability of the regional climate model REMO to different coordinated regional climate downscaling EXperiment (CORDEX) regions. Atmosphere (Basel) 3, 181-199. https://doi.org/10.3390/atmos3010181.

Jacob, D., Petersen, J., Eggert, B., Alias, A., Christensen, O.B., Bouwer, L.M., Braun, A., Colette, A., Déqué, M., Georgievski, G., Georgopoulou, E., Gobiet, A., Menut, L. Nikulin, G., Haensler, A., Hempelmann, N., Jones, C., Keuler, K., Kovats, S., Kröner, N., Kotlarski, S., Kriegsmann, A., Martin, E., van Meijgaard, E., Moseley, C., Pfeifer, S., Preuschmann, S., Radermacher, C., Radtke, K., Rechid, D., Rounsevell, M., Samuelsson, P., Somot, S., Soussana, J.F., Teichmann, C., Valentini, R., Vautard, R., Weber, B., Yiou, P., 2014. EURO-CORDEX: new highresolution climate change projections for European impact research. Reg. Environ Chang. 14, 563-578, https://doi.org/10.1007/s10113-013-0499-2.

Jakob, C., Klein, S.A., 1999. The role of vertically varying cloud fraction in the parametrization of microphysical processes in the ECMWF model. Q. J. R. Meteorol. Soc. 125, 941-965. https://doi.org/10.1002/qj.49712555510.

Jiang, X., Li, T., Wang, B., 2004. Structures and mechanisms of the northward propagating boreal summer intraseasonal oscillation. J. Clim. 17, 1022-1039. https://doi.org/10.1175/1520-0442(2004)017<1022:SAMOTN>2.0.CO;2.
Joseph, P.V., Raman, P.L., 1996. Existence of low level westerly jet stream over peninsular India during July. Ind. J. Meteorol. Geophys. 7 (1), 407-410.

Jungclaus, J.H., Fischer, N., Haak, H., Lohmann, K., Marotzke, J., Matei, D., Mikolajewicz, U., Notz, D., Von Storch, J.S., 2013. Characteristics of the ocean simulations in the Max Planck Institute Ocean Model (MPIOM) the ocean component of the MPI-Earth system model. J. Adv. Model. Earth Syst. 5, 422-446. https://doi. org/10.1002/jame.20023.

Karmacharya, J., Jones, R., Moufouma-Okia, W., New, M., 2017. Evaluation of the added value of a high-resolution regional climate model simulation of the South Asian summer monsoon climatology. Int. J. Climatol. 37, 3630-3643. https://doi.org/ 10.1002/joc.4944.

Kendon, E.J., Roberts, N.M., Senior, C.A., Roberts, M.J., 2012. Realism of rainfall in a very high-resolution regional climate model. J. Clim. 25, 5791-5806. https://doi. org/10.1175/JCLI-D-11-00562.1.

Kumar, D., Dimri, A.P., 2020. Context of the added value in coupled atmosphere-land RegCM4-CLM4.5 in the simulation of Indian summer monsoon. Clim. Dyn. 1, 3. https://doi.org/10.1007/s00382-020-05481-2.

Kumar, V., Kleissl, J., Meneveau, C., Parlange, M.B., 2006. Large-eddy simulation of a diurnal cycle of the atmospheric boundary layer: atmospheric stability and scaling issues. Water Resour. Res. 42 https://doi.org/10.1029/2005WR004651.

Kumar, P., Wiltshire, A., Mathison, C., Asharaf, S., Ahrens, B., Lucas-Picher, P., Christensen, J.H., Gobiet, A., Saeed, F., Hagemann, S., Jacob, D., 2013. Downscaled climate change projections with uncertainty assessment over India using a high resolution multi-model approach. Sci. Total Environ. 468-469, S18-S30. https://doi. org/10.1016/j.scitotenv.2013.01.051.

Kumar, P., Podzun, R., Hagemann, S., Jacob, D., 2014a. Impact of modified soil thermal characteristic on the simulated monsoon climate over South Asia. J. Earth Syst. Sci. 123, 151-160. https://doi.org/10.1007/s12040-013-0381-0.

Kumar, P., Sein, D., Cabos, W., Jacob, D., 15-19 December 2014. Improved precipitation extremes and climatology in a regional coupled model simulation over CORDEX south Asia domain. AGU Fall Meeting. https://agu.confex.com/agu/fm14/meetinga pp.cgi/Paper/16921.

Kumar, P., Sein, D., Cabos, W., Jacob, D., 2014c. Improvement of simulated monsoon precipitation over South-Asia with a regionally coupled model ROM. In: Bärring, L., Reckermann, M., Rockel, B., Rummukain, M. (Eds.), 3rd International Lund Regional-Scale Climate Modelling Workshop 21st Century Challenges in Regional Climate Modelling: Workshop proceedings, Lund, Sweden.

Kumar, P., Kotlarski, S., Moseley, C., Sieck, K., Frey, H., Stoffel, M., Jacob, D., 2015. Response of Karakoram-Himalayan glaciers to climate variability and climatic change: a regional climate model assessment. Geophys. Res. Lett. 42, 1818-1825. https://doi.org/10.1002/2015GL063392.

Kupiainen, M., Samuelsson, P., Jones, C., Jansson, C., Willén, U., Hansson, U., Ullerstig, A., Wang, S., Döscher, R., 2011. Rossby Centre Regional Atmospheric Model, RCA4. Rossby Centre Newsletter.

Li, L., Li, W., Jin, J., 2014. Improvements in WRF simulation skills of southeastern United States summer rainfall: physical parameterization and horizontal resolution. Clim. Dyn. 43, 2077-2091. https://doi.org/10.1007/s00382-013-2031-2.

Lucas-Picher, P., Christensen, J.H., Saeed, F., Kumar, P., Asharaf, S., Ahrens, B., Wiltshire, A.J., Jacob, D., Hagemann, S., 2011. Can regional climate models represent the Indian monsoon? J. Hydrometeorol. 12, 849-868. https://doi.org/ 10.1175/2011JHM1327.1.

Mandke, S.K., Pillai, P.A., Sahai, A.K., 2020. Simulation of monsoon intra-seasonal oscillations in geophysical fluid dynamics laboratory models from atmospheric model intercomparison project integrations of coupled model intercomparison project phase 5. Int. J. Climatol. 40, 5574-5589. https://doi.org/10.1002/joc.6536.

Marsland, S.J., Haak, H., Jungclaus, J.H., Latif, M., Röske, F., 2002. The Max-PlanckInstitute global ocean/sea ice model with orthogonal curvilinear coordinates. Ocean Model 5, 91-127. https://doi.org/10.1016/S1463-5003(02)00015-X.

Mass, C.F., Ovens, D., Westrick, K., Colle, B.A., 2002. Does increasing horizontal resolution produce more skillful forecasts? The results of two years of real-time numerical weather prediction over the Pacific Northwest. Bull. Am. Meteorol. Soc. 83, 407-430. https://doi.org/10.1175/1520-0477(2002)083<0407:dihrpm>2.3.co;

Maurya, R.K.S., Sinha, P., Mohanty, M.R., Mohanty, U.C., 2018. RegCM4 model sensitivity to horizontal resolution and domain size in simulating the Indian summer monsoon. Atmos. Res. 210, 15-33. https://doi.org/10.1016/j. atmosres.2018.04.010.

Mishra, A.K., Dwivedi, S., 2019. Assessment of convective parametrization schemes over the Indian subcontinent using a regional climate model. Theor. Appl. Climatol. 137, 1747-1764. https://doi.org/10.1007/s00704-018-2679-y.

Mishra, A.K., Dwivedi, S., Das, S., 2020a. Role of Arabian Sea warming on the Indian summer monsoon rainfall in a regional climate model. Int. J. Climatol. 40, 2226-2238. https://doi.org/10.1002/joc.6328.

Mishra, A.K., Dwivedi, S., Di Sante, F., Coppola, E., 2020b. Thermodynamical properties associated with the Indian summer monsoon rainfall using a regional climate model. Theor. Appl. Climatol. 141, 587-599. https://doi.org/10.1007/s00704-020-03237w.

Mishra, A.K., Dwivedi, S., Di Sante, F., 2021. Performance of the RegCM-MITgcm Coupled regional model in simulating the Indian summer monsoon rainfall. Pure Appl. Geophys.cs. https://doi.org/10.1007/s00024-020-02648-0.

Misra, V., Dirmeyer, P.A., 2009. Air, sea, and land interactions of the continental U.S. hydroclimate. J. Hydrometeorol. 10, 353-373. https://doi.org/10.1175/ 2008JHM1003.1.

Misra, V., Mishra, A., Bhardwaj, A., 2017. High-resolution regional-coupled oceanatmosphere simulation of the Indian Summer Monsoon. Int. J. Climatol. 37, 717-740. https://doi.org/10.1002/joc.5034. 
Misra, V., Mishra, A., Bhardwaj, A., 2018. Simulation of the intraseasonal variations of the Indian summer monsoon in a regional coupled ocean-atmosphere model. J. Clim. 31, 3167-3185. https://doi.org/10.1175/JCLI-D-17-0434.1.

Mukhopadhyay, P., Taraphdar, S., Goswami, B.N., Krishnakumar, K., 2010. Indian summer monsoon precipitation climatology in a high-resolution regional climate model: Impacts of convective parameterization on systematic biases. Weather Forecast. 25, 369-387. https://doi.org/10.1175/2009WAF2222320.1.

Pandey, P., Dwivedi, S., Goswami, B.N., Kucharski, F., 2020. A new perspective on ENSOIndian summer monsoon rainfall relationship in a warming environment. Clim. Dyn. 55, 3307-3326. https://doi.org/10.1007/s00382-020-05452-7.

Parthasarathy, B., Rupa, K.K., Munot, A.A., 1996. Homogeneous Regional Summer Monsoon Rainfall Over India: Interannual Variability and Teleconnections. Indian Institute of Tropical Meteorology.

Pathak, A., Ghosh, S., Kumar, P., Murtugudde, R., 2017. Role of oceanic and terrestrial atmospheric moisture sources in intraseasonal variability of Indian summer monsoon rainfall. Sci. Rep. 7 https://doi.org/10.1038/s41598-017-13115-7.

Pathak, R., Sahany, S., Mishra, S.K., Dash, S.K., 2019. Precipitation biases in CMIP5 models over the South Asian region. Sci. Rep. 9 (1), 1-3.

Paxian, A., Sein, D., Panitz, H.J., Warscher, M., Breil, M., Engel, T., Tödter, J., Krause, A., Cabos Narvaez, W.D., Fink, A.H., Ahrens, B., Kunstmann, H., Jacob, D., Paeth, H., 2016. Bias reduction in decadal predictions of West African monsoon rainfall using regional climate models. J. Geophys. Res. 121, 1715-1735. https://doi.org/ 10.1002/2015JD024143.

Peatman, S.C., Klingaman, N.P., 2018. The Indian summer monsoon in MetUMGOML2.0: effects of air-sea coupling and resolution. Geosci. Model Dev. 11, 4693-4709. https://doi.org/10.5194/gmd-11-4693-2018.

Rajendran, K., Kitoh, A., 2006. Modulation of tropical intraseasonal oscillations by ocean-atmosphere coupling. J. Clim. 19, 366-391. https://doi.org/10.1175/ JCLI3638.1.

Rajendran, K., Kitoh, A., 2008. Indian summer monsoon in future climate projection by a super high-resolution global model. Curr. Sci. 95, 1560-1569.

Ratnam, J.V., Giorgi, F., Kaginalkar, A., Cozzini, S., 2009. Simulation of the Indian monsoon using the RegCM3-ROMS regional coupled model. Clim. Dyn. 33, 119-139. https://doi.org/10.1007/s00382-008-0433-3.

Ratnam, J.V., Behera, S.K., Krishnan, R., Doi, T., Ratna, S.B., 2017. Sensitivity of Indian summer monsoon simulation to physical parameterization schemes in the WRF model. Clim. Res. 74 (1), 43-66.

Roxy, M., Ritika, K., Terray, P., et al., 2015. Drying of Indian subcontinent by rapid Indian Ocean warming and a weakening land-sea thermal gradient. Nat. Commun. 6 , 7423. https://doi.org/10.1038/ncomms8423.

Rupa, K.K., Sahai, A.K., Krishna, K.K., Patwardhan, S.K., Mishra, P.K., Revadekar, J.V., Kamala, K., Pant, G.B., 2006. High-resolution climate change scenarios for India. Curr. Sci. 90, 334-345.

Sabeerali, C.T., Ramu Dandi, A., Dhakate, A., Salunke, K., Mahapatra, S., Rao, S.A., 2013 Simulation of boreal summer intraseasonal oscillations in the latest CMIP5 coupled GCMs. J. Geophys. Res. Atmos. 118, 4401-4420. https://doi.org/10.1002/ jgrd.50403.

Saeed, F., Hagemann, S., Jacob, D., 2009. Impact of irrigation on the South Asian summer monsoon. Geophys. Res. Lett. 36, L20711 https://doi.org/10.1029/ 2009GL040625.

Saeed, F., Hagemann, S., Jacob, D., 2012. A framework for the evaluation of the South Asian summer monsoon in a regional climate model applied to REMO. Int. J. Climatol. 32, 430-440. https://doi.org/10.1002/joc.2285.

Sahai, A.K., Grimm, A.M., Satyan, V., Pant, G.B., 2003. Long-lead prediction of Indian summer monsoon rainfall from global SST evolution. Clim. Dyn. 20, 855-863. https://doi.org/10.1007/s00382-003-0306-8.

Samala, B.K., Banerjee, S., Kaginalkar, A., Dalvi, M., 2013. Study of the Indian summer monsoon using WRF-ROMS regional coupled model simulations. Atmos. Sci. Lett. 14, 20-27. https://doi.org/10.1002/asl2.409.

Sein, D.V., Mikolajewicz, U., Gröger, M., Fast, I., Cabos, W., Pinto, J.G., Hagemann, S., Semmler, T., Izquierdo, A., Jacob, D., 2015. Regionally coupled atmosphere-oceansea ice-marine biogeochemistry model ROM: 1. Description and validation. J. Adv. Model. Earth Syst. 7, 268-304. https://doi.org/10.1002/2014MS000357.

Samuelsson, P., Gollvik, S., Ullerstig, A., 2006. The land-surface scheme of the Rossby Centre regional atmospheric climate model (RCA3). Swedish Meteorological and Hydrological Institute 122, 38.
Sein, D.V., Gröger, M., Cabos, W., Alvarez-Garcia, F.J., Hagemann, S., Pinto, J.G., Izquierdo, A., Vara, A., Koldunov, N.V., Dvornikov, A.Y., Limareva, N., Alekseeva, E., Martinez-Lopez, B., Jacob, D., 2020. Regionally coupled atmosphere-ocean-marine biogeochemistry model ROM: 2 . studying the climate change signal in the North Atlantic and Europe. J. Adv. Model. Earth Syst. 12. https://doi.org/10.1029/ 2019MS001646.

Shahi, N.K., Rai, S., Sahai, A.K., Abhilash, S., 2018. Intra-seasonal variability of the South Asian monsoon and its relationship with the Indo-Pacific sea-surface temperature in the NCEP CFSv2. Int. J. Climatol. 38, e28-e47. https://doi.org/10.1002/joc.5349.

Sinha, P., Maurya, R.K.S., Mohanty, M.R., Mohanty, U.C., 2019. Inter-comparison and evaluation of mixed-convection schemes in RegCM4 for Indian summer monsoon simulation. Atmos. Res. 215, 239-252. https://doi.org/10.1016/j. atmosres.2018.09.002.

Sperber, K.R., Annamalai, H., 2008. Coupled model simulations of boreal summer intraseasonal (30-50 day) variability, part 1: systematic errors and caution on use of metrics. Clim. Dyn. 31, 345-372. https://doi.org/10.1007/s00382-008-0367-9.

Srivastava, A., Dwivedi, S., Mishra, A.K., 2016. Intercom-parison of high-resolution Bay of Bengal circulation modelsforced with different winds. Mar. Geod. 39 (3-4), 271-289.

Srivastava, A., Dwivedi, S., Mishra, A.K., 2018. Investigating the role of air - sea forcing on the variability of hydrography, circulation, and mixed layer depth in the Arabian Sea and Bay of Bengal. Oceanologia 60 (2), 169-186.

Stephens, G.L., Wood, N.B., Gabriel, P.M., 2004. An assessment of the parameterization of subgrid-scale cloud effects on radiative transfer. Part I: vertical overlap. J. Atmos. Sci. 61 (6), 715-732.

Taylor, K.E., Stouffer, R.J., Meehl, G.A., 2012. An overview of CMIP5 and the experiment design. Bull. Am. Meteorol. Soc. https://doi.org/10.1175/BAMS-D-11-00094.1.

Tiedtke, M., 1996. An Extension of Cloud-Radiation Parameterization in the ECMWF Model: the Representation of Subgrid-Scale Variations of Optical Depth. Mon. Weather Rev. 124, 745-750. https://doi.org/10.1175/1520-0493(1996)124<0745: aeocrp $>2.0 . \operatorname{co} ; 2$.

Turuncoglu, U.U., Sannino, G., 2017. Validation of newly designed regional earth system model (RegESM) for Mediterranean Basin. Clim. Dyn. 48, 2919-2947. https://doi. org/10.1007/s00382-016-3241-1.

Turuncoglu, U.U., Giuliani, G., Elguindi, N., Giorgi, F., 2013. Modelling the Caspian Sea and its catchment area using a coupled regional atmosphere-ocean model (RegCM4ROMS): model design and preliminary results. Geosci. Model Dev. 6, 283-299. https://doi.org/10.5194/gmd-6-283-2013.

Unnikrishnan, C.K., Rajeevan, M., Rao, S.V.B., Kumar, M., 2013. Development of a high resolution land surface dataset for the South Asian monsoon region. Curr. Sci. 105, 1235-1246.

Valcke, S., Caubel, A., Declat, D., Terray, L., 2003. OASIS3 Ocean Atmosphere Sea Ice Soil User's Guide, Tech. Rep. TR/CMGC/03-69, CERFACS, Toulouse, France.

Vellinga, M., Roberts, M., Vidale, P.L., Mizielinski, M.S., Demory, M., Schiemann, R., Strachan, J., Bain, C., 2016. Sahel decadal rainfall variability and the role of model horizontal resolution. Geophys. Res. Lett. 43, 326-333. https://doi.org/10.1002/ 2015 GL066690.

Webster, P.J., Magaña, V.O., Palmer, T.N., Shukla, J., Tomas, R.A., Yanai, M. Yasunari, T., 1998. Monsoons: processes, predictability, and the prospects for prediction. J. Geophys. Res. Ocean. 103, 14451-14510. https://doi.org/10.1029/ $97 \mathrm{jc} 02719$.

Yasunari, T., 1980. A quasi-stationary appearance of 30 to 40 day period in the cloudiness fluctuations during the summer monsoon over India. J. Meteorol. Soc. Japan. Ser. II 58, 225-229. https://doi.org/10.2151/jmsj1965.58.3225.

Zheng, Y., Waliser, D.E., Stern, W.F., Jones, C., 2004. The role of coupled sea surface temperatures in the simulation of the tropical intraseasonal oscillation. J. Clim. 17, 4109-4134. https://doi.org/10.1175/JCLI3202.1.

Zhu, S., Remedio, A.R.C., Sein, D.V., Sielmann, F., Ge, F., Xu, J., Peng, T., Jacob, D., Fraedrich, K., Zhi, X., 2020. Added value of the regionally coupled model ROM in the East Asian summer monsoon modeling. Theor. Appl. Climatol. 140, 375-387. https://doi.org/10.1007/s00704-020-03093-8.

Zu, T., Xue, H., Wang, D., Geng, B., Zeng, L., Liu, Q., Chen, J., He, Y., 2019. Interannual variation of the South China Sea circulation during winter: intensified in the southern basin. Clim. Dyn. 52, 1917-1933. https://doi.org/10.1007/s00382-0184230-3. 